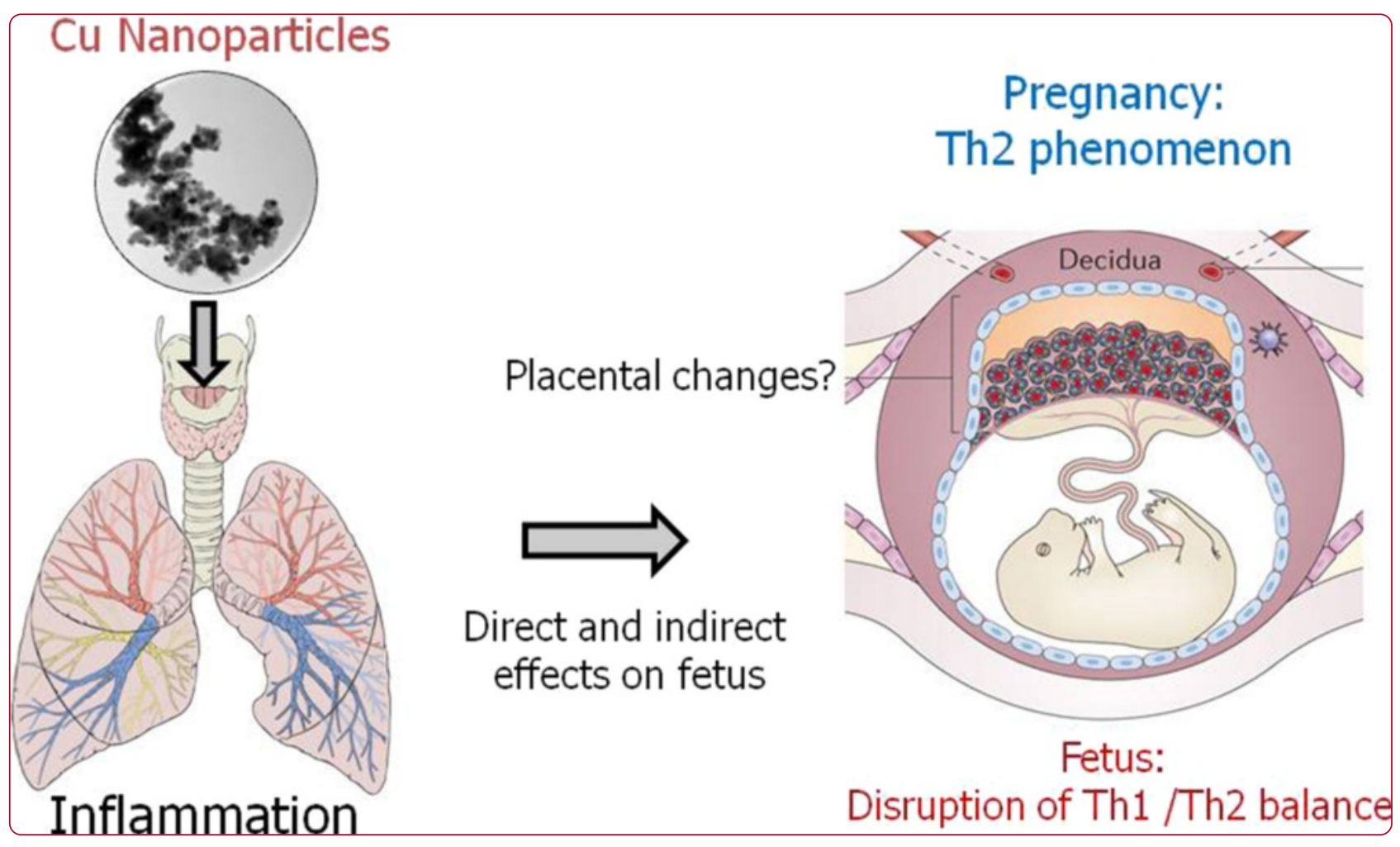

\title{
Effects of prenatal inhalation exposure to copper nanoparticles on murine dams and offspring
}

Adamcakova-Dodd et al.

C Biomed Central 
Open Access

\title{
Effects of prenatal inhalation exposure to copper nanoparticles on murine dams and offspring
}

Andrea Adamcakova-Dodd ${ }^{1 *}$, Martha M. Monick², Linda S. Powers ${ }^{2}$, Katherine N. Gibson-Corley ${ }^{3}$ and Peter S. Thorne ${ }^{1}$

\begin{abstract}
Background: Increasing numbers of individuals may be exposed to nanomaterials during pregnancy. The overarching goal of this investigation was to determine if prenatal inhalation exposure to copper nanoparticles (Cu NPs) has an effect on dams and offspring, including an analysis of inflammatory markers (Th1/Th2 cytokine profiles).

Methods: Physicochemical characterization of Cu NPs was performed. Pregnant and non-pregnant mice (C57BI/6 J) were exposed to Cu NPs or laboratory air in the whole-body chamber for 4 hrs/day on gestation days (GD) 3-19 $\left(3.5 \mathrm{mg} / \mathrm{m}^{3}\right)$. Animals were euthanized on GD 19 (0 week) or 7 weeks later. Bronchoalveolar lavage (BAL) fluid was analyzed for total and differential cells. Cytokine/chemokine concentrations were determined in the BAL fluid and the plasma of dams/non-pregnant mice and pups. Cu content was determined in the lungs and the blood of dams/non-pregnant mice and pups, in the placentas as well as in the whole bodies of pups immediately after delivery. Lungs and placentas were evaluated for histopathological changes. Gene expression of the Th1/Th2 profiles were analyzed in spleens of pups.
\end{abstract}

Results: The survival rate of 7 week old pups exposed to Cu NPs was significantly lower than control pups (73 vs. 97 \%). The average litter size, male/female ratio, body weight and lenght at birth were not different between Cu NP-exposed and control mice. Both pregnant and non-pregnant mice exposed to Cu NPs had significant pulmonary inflammation with increased number of neutrophils in the BAL fluid compared to controls. Perivascular lymphoplasmacytic cuffing was found in the lungs of exposed mice and was more pronounced in the non-pregnant group. Similarly, levels of inflammatory cytokines/chemokines IL-12(p40), G-CSF, GM-CSF, KC, MCP-1, MIP-1a, MIP-1 3 , RANTES and TNF-a in BAL fluid were significantly higher in non-pregnant than pregnant exposed mice. Histopathology evaluation of placentas did not identify any pathological changes. No translocation of Cu into the placenta or the fetus was found by inductively coupled plasma-mass spectroscopy. Expression of several Th1/Th2 or other immune response genes in pups' spleens were found to be significantly up- or down-regulated.

Conclusions: Prenatal exposure to Cu NPs caused a profound pulmonary inflammation in dams and strong immunomodulatory effects in offspring. There was no clear polarization of genes expressed in pups' spleens towards Th1 or Th2 type of response.

Keywords: Copper nanoparticles, Prenatal, Inhalation, Toxicity, Pregnancy, Mice, Th1/Th2 profiles, Immunotoxicity

\footnotetext{
* Correspondence: andrea-a-dodd@uiowa.edu

${ }^{1}$ Department of Occupational and Environmental Health, University of lowa, College of Public Health, UI Research Park, IREH 170, lowa City, IA 52242, USA Full list of author information is available at the end of the article
} 


\section{Background}

Human exposure to ultrafine particles in ambient air has been associated with adverse health outcomes including pulmonary and cardiovascular diseases [1-3], lung cancer [4], allergy and with adverse pregnancy outcomes such as premature birth, reduced birth weight, small size for gestational age and still birth [5]. Animal studies demonstrate that in utero exposure to fine and ultra-fine particles leads to multiple deleterious immunological changes in offspring, such an inhibition of Th1 maturation and postnatal asthma development $[6,7]$. It has been shown that in many cases nanoparticles (NPs) are taken up by cells and induce production of pro-inflammatory cytokines and can likely have immunomodulatory effects on the exposed organism [8].

With the fast development of nanotechnology the potential risks of NP exposure to human health is expanding. A wide variety of consumer products already contain a varying array of nanomaterials including health and fitness products, targeting pharmaceuticals, cosmetics, antibacterial clothes, home and garden products, electronics and computers, and paints. Therefore, chances for exposure to engineered nanomaterials are increasing for the public as well as for individuals in the occupational environment. Inhalation is one potential route of exposure and can occur during manufacturing, accidental release of materials, use of consumer products or medical applications. Even though it is a small percentage of the population, the most vulnerable and sensitive group to the adverse effects of NP exposure are pregnant women and their developing fetuses. However, there is limited information about the effects of exposure to nanomaterials during pregnancy. The risk of these materials is not only related to the manufactured quantities and the probability of exposure but also on the reactivity and potency to biological systems, including the immune system [9]. Increased inflammation during pregnancy (including production of a number of pro-inflammatory cytokines) may negatively influence the normal fetal development and may have negative postnatal consequences.

Copper and copper oxide nanoparticles have been used and investigated for a large number of applications, such as oxidation catalysts and as a component of solar cells [10], as well as being the major element of conductive inks and pastes used in inkjet-printed electronics [11]. Other applications are being developed due to their anti-microbial, anti-biotic and anti-fungal properties when incorporated in coatings, plastics and textiles and for biomedical applications $[12,13]$.

In the last several years, an increasing number of studies have investigated the possibility of transport of nanomaterials via placenta [14-16] and their effect on the fetus [17-22]. If NPs cross the placenta, they might result in a direct effect on the fetus. Indeed an ex vivo study of barrier capacity of human placenta found that polystyrene particles $(50,80,240$, and $500 \mathrm{~nm})$ were able to penetrate the placental barrier [15]. Similarly, an in vivo study in mice showed that quantum dots crossed the placental barrier [17]. There might also be indirect effects of prenatal inhalation exposure to NPs on the developing fetus. Up to now, there are a limited numbers of studies that focused their research on in utero effects of NPs after repeated inhalation exposure $[18,19,23]$. These studies show that even after inhalation exposure during gestation, NPs can directly or indirectly affect offspring. Inhaled cadmium oxide NPs negatively impacted fetal and neonatal development and growth [18]. Inhalation of nano-sized coated $\mathrm{TiO}_{2}$ during gestation caused lung inflammation in adult mice and neurobehavioral changes in offspring [19]. In utero pulmonary exposure to carbon black induced liver DNA damage in dams and offspring [23]. Furthermore, as it was addressed recently by Hougaard et al. [24], there is a lot of uncertainties about embryo-fetal development and health later in life after inhalation exposure to NPs and more studies in this area are warranted.

Normal pregnancy is a complex immunological state. There is a shift from Th1 to Th2 responses that functionally induces maternal tolerance and immunosuppression and protects the fetus [25]. Since nanomaterials have varying biological properties, each NP can cause disparate modulation of the immune system. For example, two catalytically different metallic NPs have shown nearly opposite effects on Th1/Th2 polarization. While titanium dioxide $\left(\mathrm{TiO}_{2}\right)$ NPs potentiated polarization towards Th1-responses, cerium oxide $\left(\mathrm{CeO}_{2}\right)$ induced Th2dominated responses [8].

The objective of this study was to assess the effects of inhalation exposure to $\mathrm{Cu}$ NPs on dams and offspring in utero using a murine pregnancy model. Based on previous studies investigating $\mathrm{Cu}$ NPs [26, 27], we expected robust inflammatory responses in particle-exposed mothers. We sought to determine if prenatal exposure to inhaled $\mathrm{Cu}$ NPs had an effect on 1) basic gestational and developmental parameters, 2) immune/inflammatory responses in the mother during pregnancy compared to non-pregnant mice, 3) translocation of $\mathrm{Cu}$ NPs through placental barrier into the fetus, 4) basic pathology of placenta, and 5) immune responses in offspring (expression of Th1/Th2 and other immune response genes in spleens).

\section{Results}

The experimental design, exposure timeline as well as number of animals per each time point shown in Fig. 1 highlights evaluation of dams, non-pregnant mice and pups immediately after prenatal exposure to $\mathrm{Cu}$ NPs and 50 days later when adolescent pups were evaluated. There were 4 experimental groups: pregnant exposed, pregnant control, non-pregnant exposed and non-pregnant control 


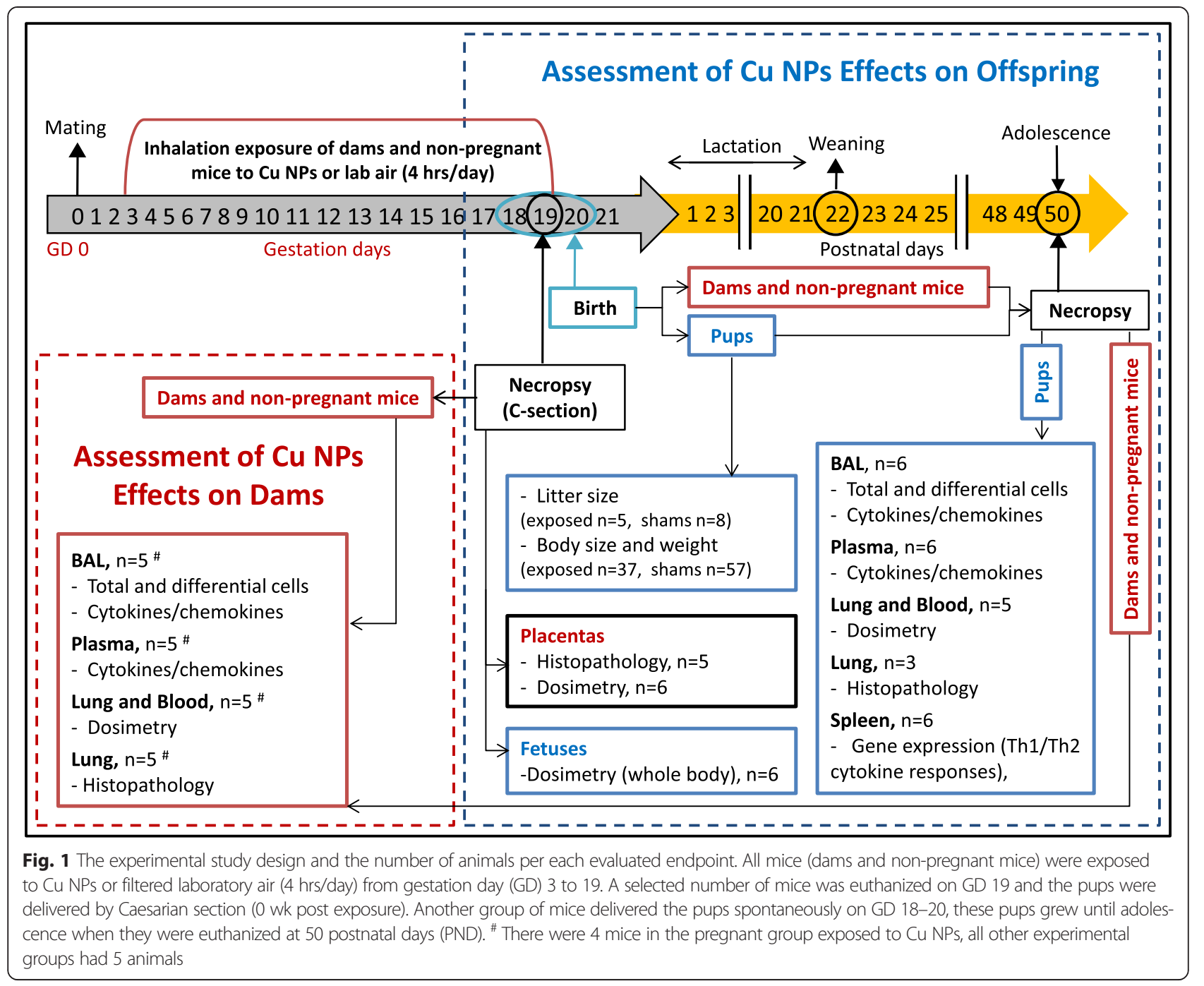

group. Non-pregnant mice received the same exposure and were necropsied at the same time as pregnant groups.

\section{Physicochemical characterization of NPs}

The size of the $\mathrm{Cu}$ NPs evaluated by TEM (Fig. 2a, b) showed an average primary particle size of $15.7 \pm 9.6 \mathrm{~nm}$ (smaller than the manufacturer's stated size of $25 \mathrm{~nm}$ ). The surface area of primary particles measured by BET analyses was $14.6 \pm 0.5 \mathrm{~m}^{2} / \mathrm{g}$ (Table 1). Powder XRD of the nanomaterial characterized immediately after opening the sealed package containing the nanoparticles showed the presence of metallic $\mathrm{Cu}$ along with the presence of $\mathrm{Cu}_{2} \mathrm{O}$ (cuprite). During handling the nanomaterial for aerosol generation and during storage, $\mathrm{Cu}$ NPs powder was exposed to the ambient environment. XRD analyses of these particles showed they aged and further oxidized leading to the presence of two phases: the metallic copper phase and a more oxidized coating of $\mathrm{CuO}$ (tenorite) on the surface of the particle. The average mobility diameter of airborne particles in the exposure chamber was $35.6 \mathrm{~nm}$ with $\mathrm{GSD}=1.7 \mathrm{~nm}$ (Table 1 , Fig. 2c).

\section{Gestational parameters}

During the time of exposure, pregnant exposed mice gained significantly less weight than pregnant controls $(p<0.05$, ANOVA for repeated measures). In nonpregnant groups, there was no statistical difference in weight gain (Fig. 3a). Both male and female pups with prenatal exposure to $\mathrm{Cu}$ NPs gained significantly less weight during postnatal days than their control counterparts (Fig. 3b). Survival rate of pups was significantly $(p<0.001)$ lower in exposed mice than controls (Fig. 3c, Table 2). Only $73 \%$ of pups with prenatal exposure to $\mathrm{Cu}$ NPs survived up to 50 PNDs compared to $97 \%$ of controls. All of the pups that died were lost in the first 2 weeks (wks) after delivery, with $16 \%$ loss at 1 week (wk) and $27 \%$ loss at 2 wks after delivery. The length of 


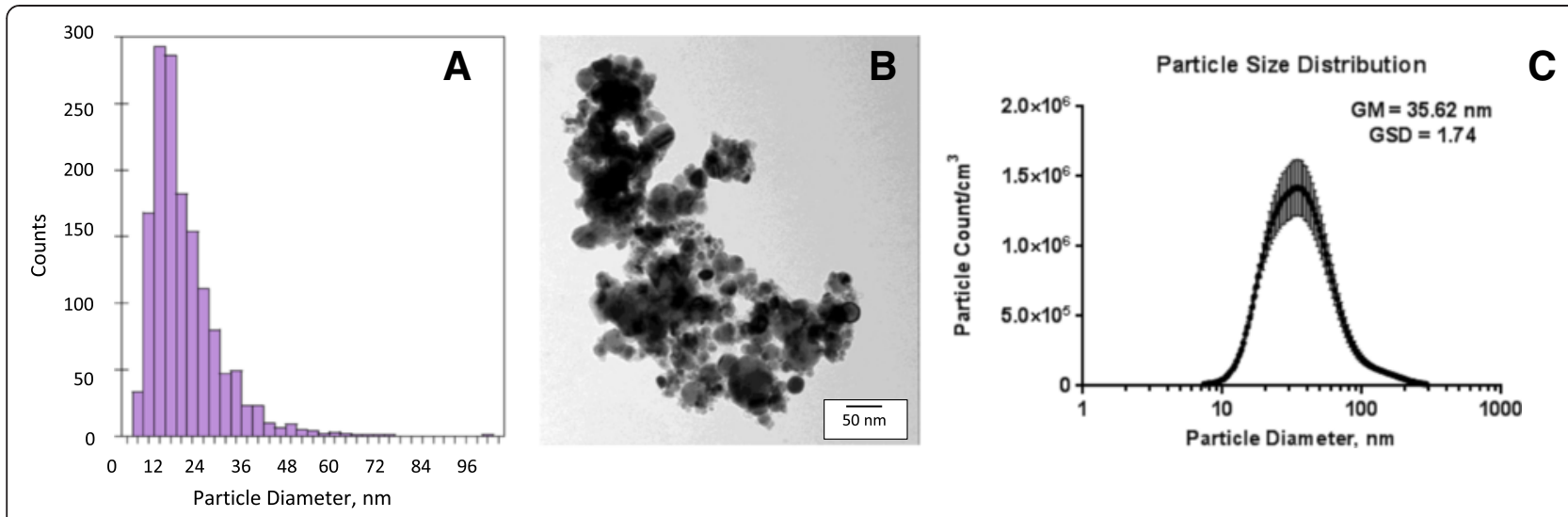

Fig. 2 Characterization of Cu NPs. Particle size distribution of primary Cu NPs (a) TEM image of primary Cu NPs (b), and the size distribution of generated Cu NP aerosol in the whole-body exposure chamber (c)

gestation as well as average litter size was slightly lower in exposed mice than controls, but not significantly. There were no other significant differences between exposed and control mice in the following parameters (Table 2): gestation length, average litter size, male/female ratio, birth weight, and birth body length. Each dam delivered between 6-9 pups with an average litter size of $6.2 \pm 1.1$ in exposed group and $7.1 \pm 2.7$ in control group (means \pm standard deviations).

\section{Evaluation of BAL fluid cells Pregnant and non-pregnant mice}

The total number of white blood cells recovered by BAL at 0 wk after exposure was significantly higher in $\mathrm{Cu}-\mathrm{NP}$ exposed pregnant $\left(5710 \pm 1550 \times 10^{3}\right.$ cells per mouse $)$ or non-pregnant mice $\left(5840 \pm 720 \times 10^{3}\right.$ cells per mouse $)$ compared to their sham counterparts $(p<0.05$ and $p<$ 0.001 , respectively, Fig. 4a). This major increase was 53 -fold in pregnant and 81-fold in non-pregnant $\mathrm{Cu}-\mathrm{NP}$-exposed mice compared to their controls. The number of cells decreased 7 wks after the exposure, but there was still a significant 8-fold $(p<0.001)$ and 6-fold $(p<0.01)$ increase in exposed pregnant and non-pregnant mice, respectively compared to their controls. There was no significant change in recruitment of total cells into the lungs between exposed pregnant and non-pregnant mice. The number of macrophages in BAL fluid showed a similar trend as the total number of cells, with the highest recruitment in nonpregnant $\mathrm{Cu}-\mathrm{NP}$-exposed mice at 0 wk post exposure $\left(3314 \pm 538 \times 10^{3}\right.$ cells per mouse), followed by pregnant $\mathrm{Cu}$-NP-exposed group $\left(3083 \pm 937 \times 10^{3}\right.$ cells per mouse $)$ at $0 \mathrm{wk}$ post exposure. The number of macrophages was significantly higher in both exposed groups compared to shams (Fig. 4b).

Recruitment of neutrophils into the airways immediately after the last exposure was also significantly increased in both pregnant $\left(2320 \pm 820 \times 10^{3}\right.$ cells per mouse, $p<0.05)$ and non-pregnant $\left(1850 \pm 670 \times 10^{3}\right.$ cells per mouse, $p<0.01)$ exposed groups compared to their pregnant and non-pregnant controls $(0.5 \pm 0.2$ and $0.4 \pm 0.2$, respectively). At 7 wks post exposure, the number of neutrophils was found to be similar to controls (Fig. 4c). The number of lymphocytes in BAL fluid per mouse at 0 wk after exposure was significantly $(p<0.05)$ increased (Fig. 4d) in exposed pregnant $(304 \pm 114 \times$ $\left.10^{3}\right)$ and non-pregnant mice $\left(681 \pm 180 \times 10^{3}\right)$ compared to pregnant and non-pregnant controls $\left(0.9 \pm 0.4 \times 10^{3}\right.$ and $1 \pm 0.1 \times 10^{3}$, respectively). No eosinophils were found in BAL fluid.

\section{Pups}

Spontaneously delivered pups were necropsied at 50 PND. The total number of cells in BAL fluid was increased in pups with prenatal exposure to $\mathrm{Cu}$ NPs $\left(293 \pm 66 \times 10^{3}\right.$ cells per mouse) compared to controls $\left(155 \pm 23 \times 10^{3}\right.$ cells per mouse), but this increase was not significant $(p<0.06)$. The number of macrophages was significantly $(p<0.02)$ increased in prenatally exposed pups $\left(223 \pm 36 \times 10^{3}\right.$ cells per mouse), compared to controls (152 $\pm 22 \times 10^{3}$ cells per mouse) while the number of neutrophils and lymphocytes in BAL fluid did not differ from controls (Fig. 5). No eosinophils were found in BAL fluid.

Table 1 Physicochemical characterization of Cu NPs

\begin{tabular}{ll}
\hline Particle characteristic & Cu NPs \\
\hline Primary particle diameter & $15.7 \pm 9.6 \mathrm{~nm}$ \\
BET surface area & $14.6 \pm 0.5 \mathrm{~m}^{2} / \mathrm{g}$ \\
Particle size in the exposure chamber & $\mathrm{GM}=35.6 \mathrm{~nm}$ \\
& $\mathrm{GSD}=1.7 \mathrm{~nm}$ \\
Exposure aerosol concentration & $3.5 \pm 1.2 \mathrm{mg} / \mathrm{m}^{3}$ \\
\hline
\end{tabular}



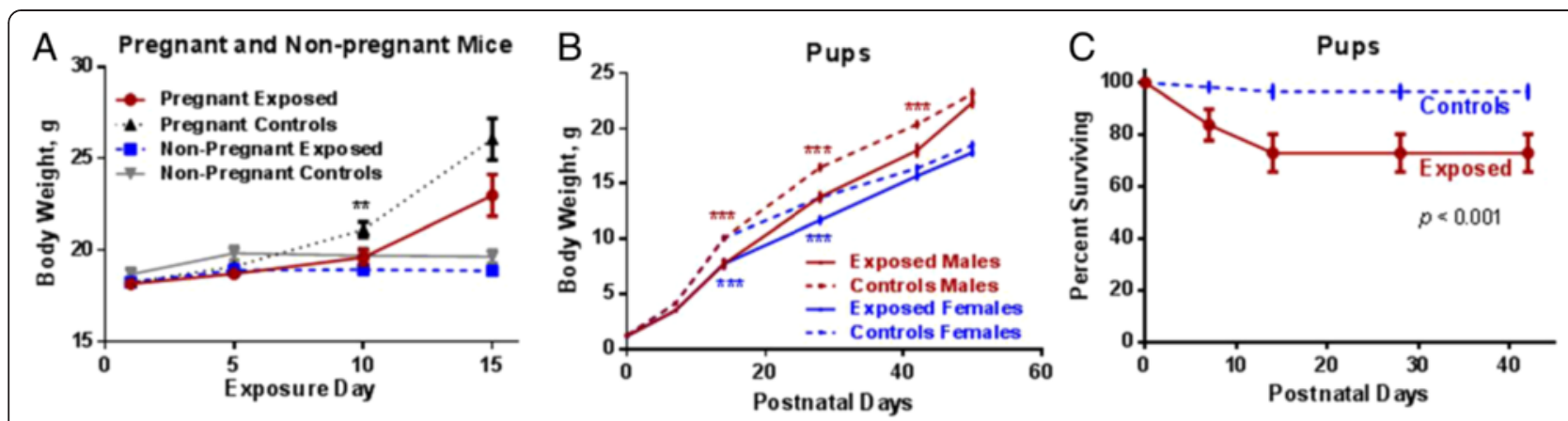

Fig. 3 Body weights of all animals and survival rate of pups. The body weights of pregnant and non-pregnant mice during Cu NPs exposure (a). Postnatal body weights of pups (b) and postnatal survival rate of pups after prenatal inhalation exposure to Cu NPs (c). Significant value ${ }^{* *} p<0.1$ in a represents the comparison between pregnant exposed vs. pregnant controls. Significant value ${ }^{* *} p<0.001$ in $\mathbf{b}$ represents the comparison between exposed males vs. control males and exposed females vs. control females pups

\section{Cytokines in BAL fluid and plasma}

An array-based analysis panel of 23 cytokines/chemokines was used to analyze supernatants of BAL fluid from dams/ non-pregnant mice at 0 day post exposure and pups at 50 PNDs. Of the proteins tested from BALs, some cytokines were below lowest limit of detection: IL-1 $\alpha$, IL-2, IL-3, IL-4, IL-5 and IL-12(p70). The concentration of IL-10 was very low in non-pregnant groups and not detected in pregnant mice. Cytokines that were detectable in adult females' BAL fluid were higher in both exposed groups of mice (pregnant and non-pregnant) compared to controls. The concentrations of the following cytokines were significantly higher in exposed non-pregnant mice compared to exposed pregnant mice: IL-1 $\beta$, TNF- $\alpha$, and IL-6 (in Th1 group, Fig. $6 \mathrm{a}$ ), RANTES, G-CSF and GM-CSF (in Th2 group, Fig. 6b), MCP-1, MIP- $1 \alpha$, MIP- $1 \beta$ and KC (in other cytokines/ chemokine group, Fig. $6 \mathrm{c}$ ). The highest chemokine level in BAL fluid among Cu-NP-exposed mice was MCP-1, with a 4-fold higher concentration in non-pregnant mice $(7930 \pm 1880 \mathrm{pg} / \mathrm{mL})$ compared to pregnant mice (1710 \pm $700 \mathrm{pg} / \mathrm{mL})$. The second highest concentration was IL12(p40) with a 4-fold higher concentration in exposed nonpregnant mice $(940 \pm 100 \mathrm{pg} / \mathrm{mL})$ compared to exposed pregnant mice $(220 \pm 40 \mathrm{pg} / \mathrm{mL})$. For the pups, the majority of the cytokines/chemokines were not detected with the exception of IL-9, IL-12(p40), IL-13, IL-17, IFN- $\gamma, \mathrm{KC}$, and TNF- $\alpha$. However there were no significant concentration differences in pups with prenatal $\mathrm{Cu}$-NP-exposure vs. controls (data not shown).
The same array of cytokines/chemokines was analyzed in the plasma of dams/non-pregnant mice and pups. Cytokines that were significantly elevated in the plasma of nonpregnant exposed mice compared to non-pregnant controls as well as compared to pregnant mice exposed to $\mathrm{Cu}$ NPs included: IL-12(p40), IL-6, and G-CSF (Fig. 6d and e). The concentrations of cytokines/chemokines in the plasma of pups were very low and there were no significant differences between exposed and control pups (data not shown).

\section{Histopathology of lungs and placenta}

Lung tissue evaluations of controls and exposed dams/ non-pregnant mice showed a negative effect of NP inhalation in all exposed groups compared to controls. The pathology findings were minor but more pronounced in non-pregnant mice as opposed to the pregnant group (Fig. 7 and Table 3). There were varying amounts of amorphous alveolar debris and foamy alveolar macrophages in the lungs of exposed mice, both pregnant and non-pregnant. Neutrophilic alveolar inflammation, represented by multifocal pockets of neutrophils within the lungs, was only found in non-pregnant exposed mice at day 0 . Similarly, perivascular lymphoplasmacytic cuffing was most distinct in the non-pregnant day 0 group, but was also present in both exposed groups at day 50 post exposure. Cuffing at day 50 was less prominent than at 0 day post exposure and was more multifocal. There were no notable pathology findings in either the lungs from the pups or the placentas in either the sham or the exposed

Table 2 Gestational parameters

\begin{tabular}{|c|c|c|c|c|c|c|}
\hline Spontaneous birth: & $\begin{array}{l}\text { Gestation length, } \\
\text { days } \pm \text { SD }\end{array}$ & $\begin{array}{l}\text { Average litter } \\
\text { size, } \pm \text { SD }\end{array}$ & Male/female (ratio) & Birth weight $\pm S E, g$ & $\begin{array}{l}\text { Body length at } \\
\text { birth } \pm S E, m m\end{array}$ & $\begin{array}{l}\text { Survival rate at } \\
50 \text { PNDs }\end{array}$ \\
\hline Exposure & $18.4 \pm 0.6$ & $6.2 \pm 1.1$ & $14 / 13(1.08)$ & $1.22 \pm 0.01$ & $25.00 \pm 0.16$ & $73 \% * * *$ \\
\hline Controls & $19.0 \pm 0.0$ & $7.1 \pm 2.7$ & 29/26 (1.12) & $1.28 \pm 0.01$ & $24.93 \pm 0.13$ & $97 \%$ \\
\hline
\end{tabular}

$S D$ standard deviation

PND - postnatal days

${ }^{* * *} p<0.001$ significantly lower survival rate compared to controls 

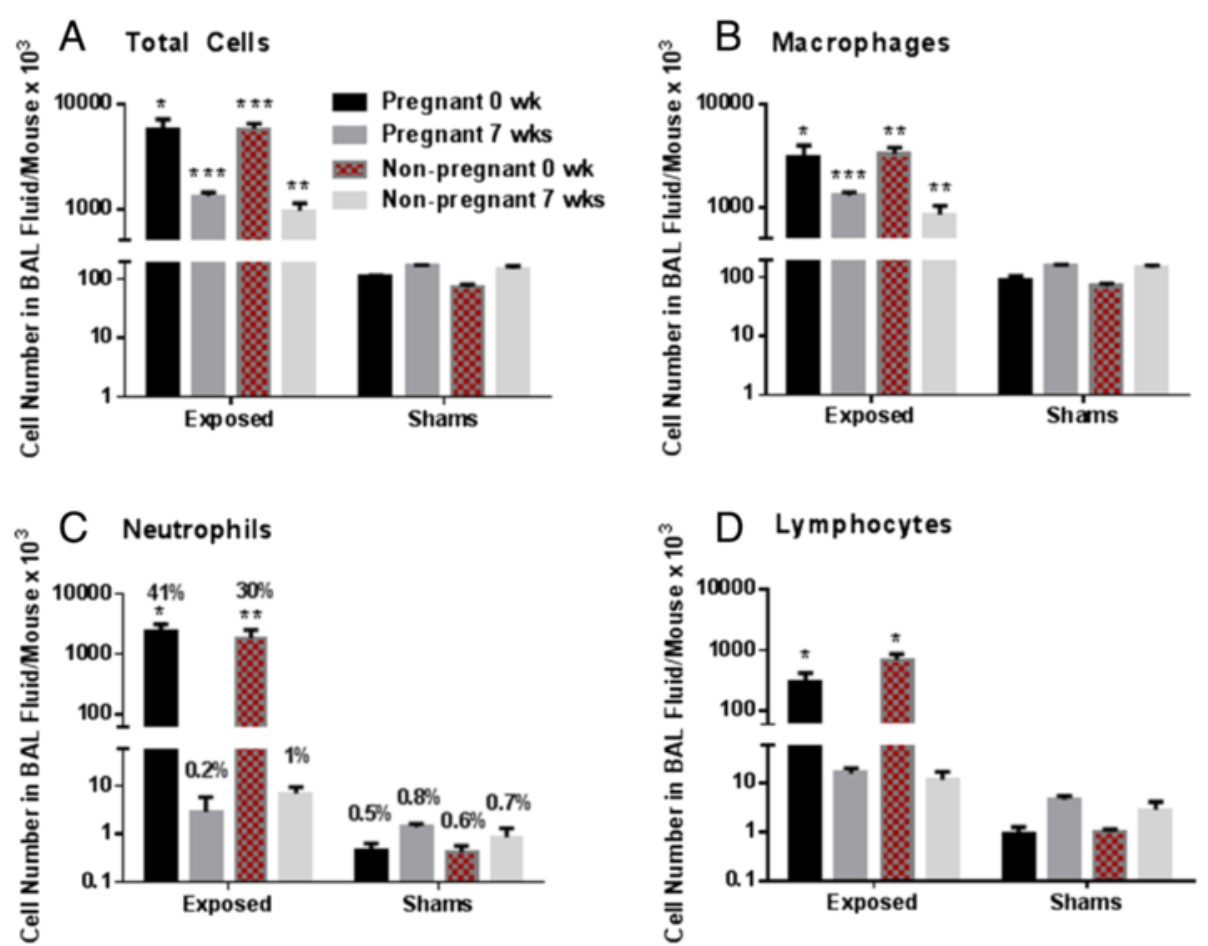

Fig. 4 Cell numbers in BAL fluid of exposed and control pregnant and non-pregnant mice. A comparison of the number of total cells (a), macrophages (b), neutrophils (c) and lymphocytes (d) in the BAL fluid in pregnant and non-pregnant mice exposed to Cu NPs and their sham counterparts. c the percentage of neutrophils out of the total number of cells is also shown. Values are expressed as mean \pm SE. Statistically significant differences between exposed groups and control counterparts (shams) are indicated as follows: ${ }^{*} p<0.05,{ }^{* *} p<0.01$ and ${ }^{* * *} p<0.001$

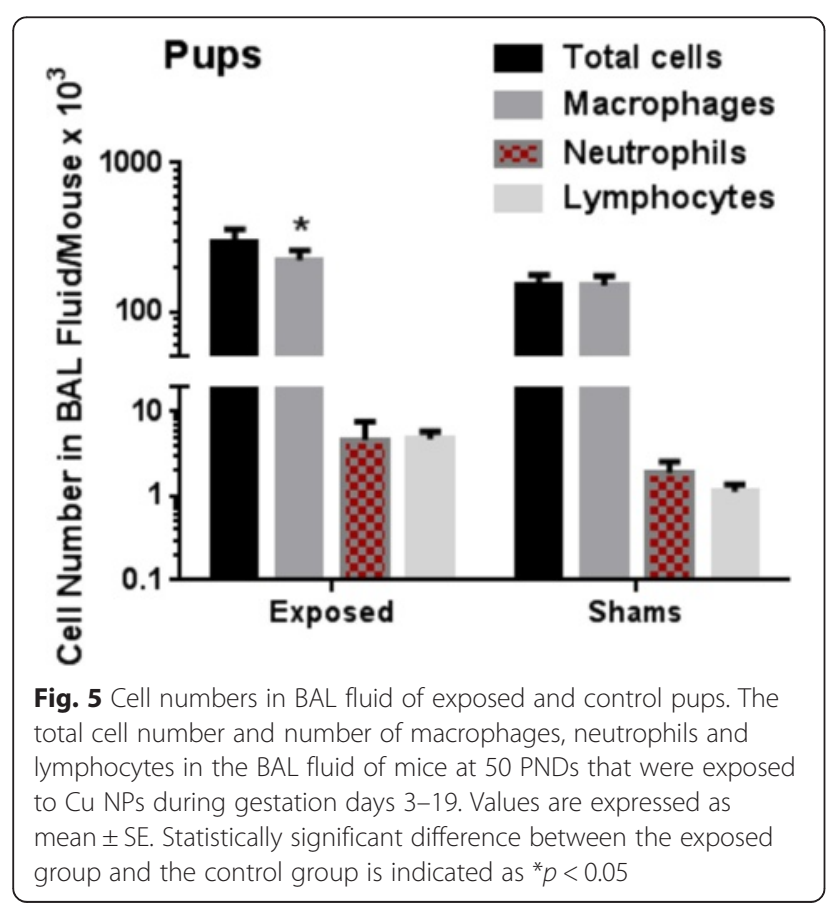

groups. The morphology of major vessels and capillaries in placenta were evaluated as well as the labyrinth, decidual and spongiotrophoblast layers were measured in all placental tissues and no significant differences were noted (Additional file 1).

\section{Determination of Cu levels}

$\mathrm{Cu}$ was measured by ICP-MS in the whole blood and in the lungs of pregnant and non-pregnant mice, placentas, fetuses delivered by Caesarian section (C-section) at GD 19, and pups (whole blood) at 50 PND (Table 4). There was no significant difference in $\mathrm{Cu}$ concentration in the whole blood between exposed dams and controls. Both groups of pregnant mice, exposed as well as shams, had a 2 -fold increase in $\mathrm{Cu}$ levels in the whole blood, compared to non-pregnant mice. Interestingly, the inhalation of $\mathrm{Cu}$ NPs did not elevate $\mathrm{Cu}$ concentrations in the blood of exposed animals. The levels of $\mathrm{Cu}$ in the lung tissue of exposed pregnant mice $(85.9 \pm 3.9 \mu \mathrm{g} / \mathrm{L})$ at 0 PND were increased significantly $(p<0.001)$ compared to pregnant shams $(23.4 \pm 4.1)$. Also highly significant elevation $(p<$ 0.0001 ) of $\mathrm{Cu}$ levels in the lungs was found in nonpregnant exposed $(54.4 \pm 2.8 \mu \mathrm{g} / \mathrm{L})$ mice compared to non-pregnant shams $(13.0 \pm 1.2 \mu \mathrm{g} / \mathrm{L})$. The levels of $\mathrm{Cu}$ in lung tissue of exposed pregnant and non-pregnant mice were 3.7 - and 4.2-times higher, respectively, compared to 

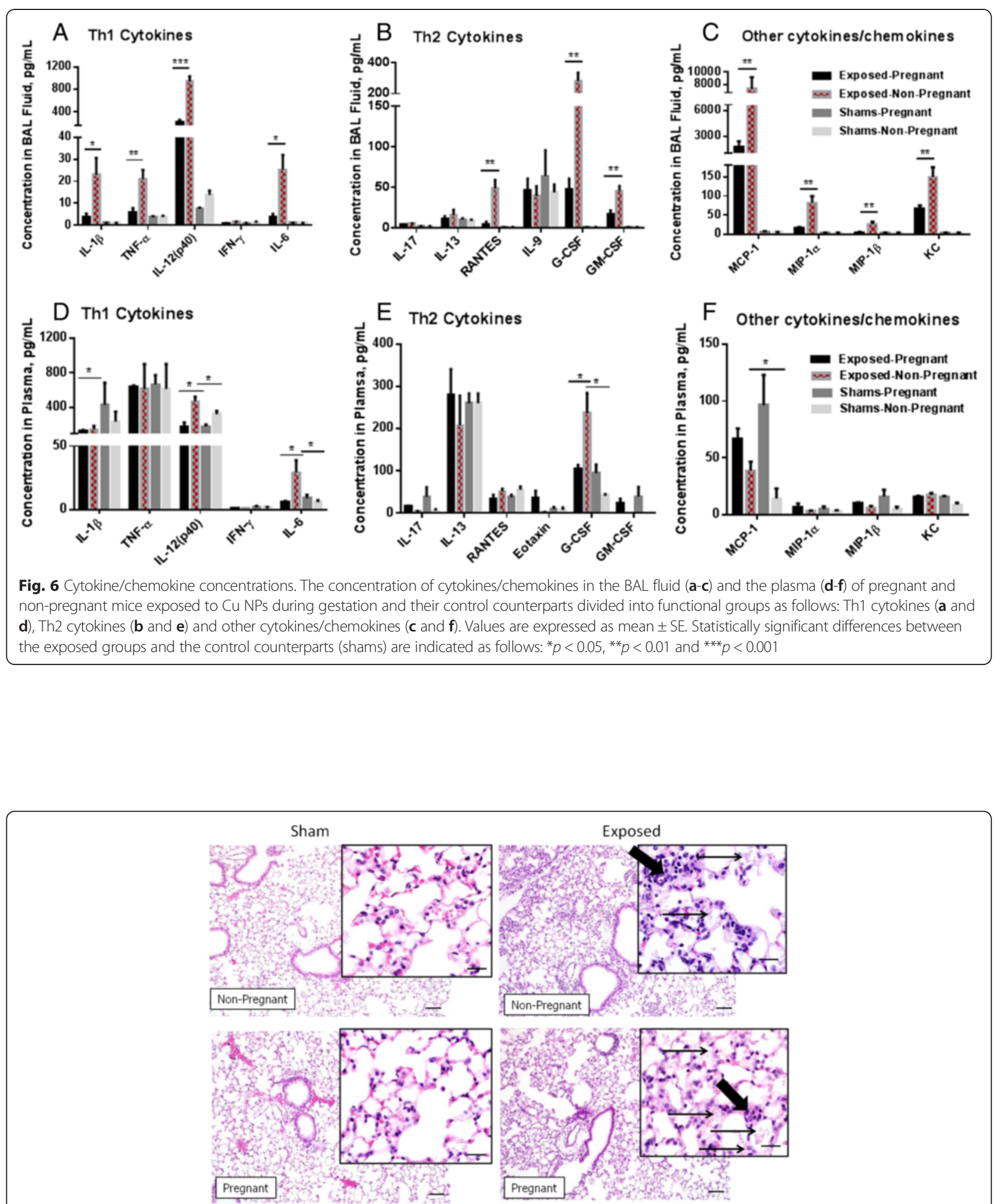

Fig. 7 Lung histopathology. Lung from mice exposed to Cu NPs and euthanized immediately after C-section on GD 19 (0 PND) exhibited histopathologic changes including mild to moderate, multifocal inflammatory cell infiltration within the interstitium which is composed primarily of lymphocytes and neutrophils with fewer plasma cells and macrophages (thick arrows). Also present was multifocal accumulations of a basophilic, flocculent, amorphous material (thin arrows). The pathology findings were more pronounced in non-pregnant mice as opposed to the pregnant group. There were no pathologic findings in control mice. Bars $=200 \mu \mathrm{m}$ (inset, bars $=20 \mu \mathrm{m}$ ) 
Table 3 Histopathology scores of exposed and control pregnant and non-pregnant groups immediately after delivery on GD 19 (PND 0) and 50 days later (PND 50)

\begin{tabular}{|c|c|c|c|c|c|}
\hline \multirow{2}{*}{\multicolumn{2}{|c|}{ Experimental Group }} & \multirow{3}{*}{$\begin{array}{l}\begin{array}{l}\text { Number of mice } \\
\text { per group }\end{array} \\
n=4\end{array}$} & \multirow{2}{*}{\multicolumn{3}{|c|}{ Histopathology Score ${ }^{a}$}} \\
\hline & & & & & \\
\hline Exposed & Pregnant, PND 0 & & $\begin{array}{c}\text { Alveolar macrophages } \\
1\end{array}$ & $\frac{\text { Alveolar debris }}{2}$ & $\begin{array}{c}\text { Perivascular cuffing } \\
0.75\end{array}$ \\
\hline & Non-Pregnant, PND 0 & $n=5$ & 1 & 1 & 1.8 \\
\hline & Pregnant, PND 50 & $n=5$ & 1 & 0 & 0.2 \\
\hline & Non-Pregnant, PND 50 & $n=5$ & 0.6 & 0 & 0.2 \\
\hline \multirow[t]{2}{*}{ Shams } & Pregnant, PND 0 & $n=4^{c}$ & 0 & 0 & 0 \\
\hline & Non-Pregnant, PND 0 & $n=4^{c}$ & 0 & 0 & 0 \\
\hline
\end{tabular}

PND postnatal day

aScoring system: $0=$ none, 1 = few $/$ rare, $2=$ multifocal $/$ moderate, $3=$ many $/$ coalescing and $/$ or diffuse

bLymphocytes and plasma cells surrounding blood vessels

'Only 4 mice out of 5 were evaluated for pathology changes in control groups

controls. $\mathrm{Cu}$ concentrations in the blood as well as in lungs were found to be lower at 50 PND compared to 0 PND, but there was still 2.2- and 1.7- times increase in exposed pregnant and non-pregnant mice, respectively, compared to controls.

There was no significant difference in Cu levels in placentas $(19.9 \pm 1.8 \mathrm{mg} / \mathrm{kg}$ vs. $17.6 \pm 1.6 \mathrm{mg} / \mathrm{kg}$ ), fetuses (whole body) at GD $19(11.6 \pm 0.3 \mathrm{mg} / \mathrm{kg}$ vs. $11.1 \pm 0.5 \mathrm{mg} / \mathrm{kg})$ or in the whole blood of pups at 50 PND $(600 \pm 18.9, \mu \mathrm{g} / \mathrm{L} v s$. $655 \pm 30.0, \mu \mathrm{g} / \mathrm{L})$ between exposed group and controls, respectively.

\section{Gene expression analyses}

The mRNA expression of 84 genes involved in T-helper cell (Th cell) immune responses was determined in spleenic mRNAs of pups at 50 PNDs with prenatal exposure to $\mathrm{Cu}$ NPs and compared to control pup spleenic mRNA. Out of 84 genes, 14 genes were significantly $(p<0.05)$ up-regulated at least 2 -fold from controls and 11 genes were significantly $(p<0.05)$ down-regulated at least 2 -fold from controls (Fig. 8). The two highest up-regulated genes were Lta (Lymphotoxin A, 6-fold) and Gfil (Growth factor independent 1, 5-fold). The most significantly downregulated genes were Sftpd (Surfactant associated protein D, 630-fold, Spp1 (Secreted phosphoprotein 1, 27-fold), Csf2 (Colony stimulating factor 2 [granulocyte-macrophage], GM-CSF, 9-fold), Ccl11 (Chemokine (C-C motif) ligand 11, eotaxin, eosinophil chemokine, 7 -fold), and Tgfb3 (Transforming growth factor, $\beta 3$, 7-fold). There was no clear polarization towards Th1- or Th2-related genes. Table 5 lists only genes with fold-change $>=2$ or $\mathrm{p}-$ value $<0.1$.

\section{Discussion}

Regardless of the numerous benefits of nanotechnology applications, there is a potential health threat from nanoparticle exposure that needs to be addressed also in more susceptible populations, including pregnant women and developing fetuses. Exposure to NPs during sensitive developmental stages of life may predispose an organism to diseases later in life. In our study, we assessed the effects of prenatal inhalation of $\mathrm{Cu}$ NPs on dams and offspring using a mouse model.

Table 4 Dosimetry of Cu NPs in the whole blood, lung and placenta

\begin{tabular}{|c|c|c|c|c|c|c|c|}
\hline \multirow{2}{*}{\multicolumn{2}{|c|}{ Experimental group }} & \multicolumn{5}{|c|}{ Cu Concentration, Mean \pm SE } & \multirow{3}{*}{ Fetus (GD19), mg/kg } \\
\hline & & \multicolumn{2}{|c|}{ Whole blood, $\mu \mathrm{g} / \mathrm{L}$} & \multicolumn{2}{|l|}{ Lungs, mg/kg } & \multirow[t]{2}{*}{ Placenta, mg/kg } & \\
\hline \multicolumn{2}{|c|}{ Adult females } & PND 0 & PND 50 & PND 0 & PND 50 & & \\
\hline \multirow[t]{2}{*}{ Exposed } & Pregnant & $1400 \pm 91.7^{\# \# \#}$ & $644 \pm 7.0$ & $85.9 \pm 3.9^{* * * *}, \# \#$ & $28.5 \pm 3.4^{* *}$ & $19.9 \pm 1.8$ & $11.6 \pm 0.3$ \\
\hline & Non-Pregnant & $737 \pm 26.4$ & $669 \pm 20.7$ & $54.4 \pm 2.8^{* * *}$ & $20.0 \pm 0.6^{* * *}$ & - & - \\
\hline \multirow[t]{2}{*}{ Shams } & Pregnant & $1450 \pm 18.3$ & ND & $23.4 \pm 4.1$ & $12.8 \pm 1.0$ & $17.6 \pm 1.6$ & $11.1 \pm 0.5$ \\
\hline & Non-Pregnant & $704 \pm 13.2$ & ND & $13.0 \pm 1.2$ & $11.8 \pm 0.4$ & - & - \\
\hline \multicolumn{8}{|l|}{ Pups } \\
\hline \multicolumn{2}{|l|}{ Exposed } & - & $600 \pm 18.9$ & ND & ND & & \\
\hline \multicolumn{2}{|l|}{ Shams } & - & $655 \pm 30.0$ & ND & ND & & \\
\hline
\end{tabular}

ND not determined

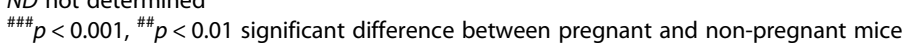

${ }^{* * *} p<0.001, * * p<0.01$ significant difference between exposed and control counterparts 


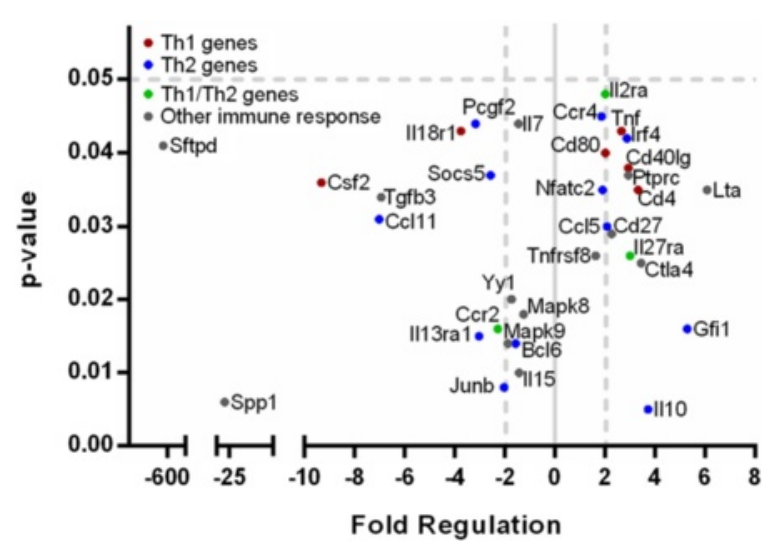

Fig. 8 Spleenic gene expression in pups. The mouse Th1 and Th2 responses were identified in RNAs isolated from the spleens of pups after prenatal exposure to Cu NPs by RT ${ }^{2}$ Profiler PCR Array (PAMM-034ZA, SABiosciences, Qiagen). Out of 84 genes, 14 genes were significantly $(p<0.05)$ up-regulated at least 2 -fold and 11 genes were significantly $(p<0.05)$ down-regulated at least 2 -fold from the controls

We performed physicochemical characterization of commercially available $\mathrm{Cu}$ NPs immediately after opening the package prior to exposure to the ambient environment, as well as after exposure that occurred during storage and handling. The primary particle size evaluated by TEM was $15.7 \pm 9.6 \mathrm{~nm}$. As expected and observed previously, $\mathrm{Cu}$ NPs can readily oxidize upon exposure to the ambient environment and this can change the properties of the original nanoparticles. The dynamic nature of $\mathrm{Cu}$ NPs is described in Mudunkotuwa et al. [28]. Oxidation of $\mathrm{Cu}$ NPs was also observed in our study during storage and handling. Initial characterization of $\mathrm{Cu}$ NPs minimally exposed to the ambient air showed the presence of mainly metallic $\mathrm{Cu}$ with a thin coating of $\mathrm{Cu}_{2} \mathrm{O}$ (cuprite) on the particle surface as shown by XPS. The XRD pattern of material exposed to the ambient environment showed the presence of two phases: metallic $\mathrm{Cu}$ and $\mathrm{CuO}$ (tenorite) only with no $\mathrm{Cu}_{2} \mathrm{O}$ phase. An average mobility diameter of airborne particles in the whole-body chamber was $35.6 \mathrm{~nm}$ with GSD $=1.7 \mathrm{~nm}$.

At present, there is not enough information available to determine a potential hazard of prenatal exposure to NPs especially by inhalation. Furthermore, the exposure limits are nowadays available only for a limited number of nanomaterials (such as $\mathrm{TiO}_{2}$ and carbon nanotubes). Since there are currently no exposure limits for $\mathrm{Cu}$ NPs, we based our animal exposure studies on the current exposure limits for coarse copper material. The Recommended Exposure Limit (REL) for copper dust and mist (not including fumes) established by the National Institute for Occupational Safety and Health (NIOSH) as well as Permissible Exposure Limit (PEL) by the Occupational Safety and Health Administration (OSHA) is $1 \mathrm{mg} / \mathrm{m}^{3}$ as a time-weighted average concentration. The estimated dose of $\mathrm{Cu}$ NPs in the tracheobronchial and pulmonary region after exposure during gestation was $141 \mu \mathrm{g} /$ mouse $(6.1 \mathrm{mg} / \mathrm{kg})$. This estimated dose corresponded to the lung dose accumulated by a human $(70 \mathrm{~kg})$ exposed to a concentration of $1 \mathrm{mg} / \mathrm{m}^{3}$ for a period of 39.7 work wks (assuming breathing frequency of 15 breaths/min, $600 \mathrm{~mL} /$ breath, and pulmonary deposition fraction for $36 \mathrm{~nm}$ particles of 0.5) [29]. The average length of a human pregnancy is $40 \mathrm{wks}$.

\section{Basic gestational and developmental parameters were affected by prenatal Cu NP exposure}

Prenatal inhalation exposure to $\mathrm{Cu}$ NPs during GD 3 - 19 had a significant effect on some basic developmental and gestational parameters. Maternal weight gain during gestation was lower in exposed pregnant mice than in controls. Similarly, pups with prenatal exposure gained weight slower than the control pups. Length of gestation, as well as litter size were also slightly (not significantly) affected by the exposure; all other basic gestational measures were not affected. It is possible that with the increased sample size per each group, these observations could become significant. The survival rate of pups at 50 PNDs was significantly lower in exposed mice than controls. Another study investigating prenatal inhalation exposure of $\mathrm{TiO}_{2}$ particles (rutile) on GD 8-18, $1 \mathrm{hr} /$ day, concentration of $42 \mathrm{mg} / \mathrm{m}^{3}$, found no effects on maternal weight gain, length of gestation, loss of implantations, litter size, offspring body weight or sex ratio. Pup survival during the lactation period was not significantly reduced in $\mathrm{TiO}_{2}$ litters [19]. Intra-tracheal exposure to carbon nanoparticles on GDs 7 - 14 (200 $\mu \mathrm{g} /$ mouse per each day) did not affect basic gestational parameters [30]. This suggests that $\mathrm{Cu}$ NPs have greater toxicity for fetuses than some other nanomaterials. The observed lower survival rate of pups with prenatal exposure to $\mathrm{Cu}$ NPs could potentially be due to reduced food intake by exposed dams caused by inflammation, secondary exposure to $\mathrm{Cu}$ NPs or $\mathrm{Cu}$ ions via lactation, or disruption/alteration of immune, inflammatory, 
Table 5 Gene expression changes in Cu NP-exposed and control pups, spleen tissue (rtPCR array)

\begin{tabular}{|c|c|c|c|c|}
\hline $\begin{array}{l}\text { Gene } \\
\text { Symbol }\end{array}$ & Gene Description & $\begin{array}{c}\text { Exposed/Controls } \\
\text { normalized, } \\
\text { fold regulation }\end{array}$ & $\begin{array}{c}\mathrm{p}- \\
\text { value }\end{array}$ & Functional gene grouping \\
\hline Lta & Lymphotoxin Alpha, TNFB & 6.08 & 0.035 & $\begin{array}{l}\text { Cell-mediated and humoral } \\
\text { Immunity, and other } \\
\text { inflammatory responses, } \\
\text { Th1 related gene }\end{array}$ \\
\hline Gfi1 & Growth factor independent 1 & 5.29 & 0.016 & Other Th2 related gene \\
\hline$\| 10$ & Interleukin 10 & 3.72 & 0.005 & $\begin{array}{l}\text { Cell-mediated immunity, Th2 } \\
\text { immune response }\end{array}$ \\
\hline Ctla4 & $\begin{array}{l}\text { Cytotoxic T-lymphocyte- } \\
\text { associated protein } 4\end{array}$ & 3.44 & 0.025 & CD4+ T-Cell Markers \\
\hline $\mathrm{Cd} 86$ & CD86 antigen & 3.40 & 0.079 & $\begin{array}{l}\text { CD4+ T-Cell Markers, Th2 } \\
\text { immune response }\end{array}$ \\
\hline $\mathrm{Cd} 4$ & CD4 antigen & 3.31 & 0.035 & $\begin{array}{l}\text { Cell-mediated immunity, CD4+ } \\
\text { T-Cell Markers }\end{array}$ \\
\hline$\| 2$ & Interleukin 2 & 3.31 & 0.147 & $\begin{array}{l}\text { Other Th1-related genes, cell- } \\
\text { mediated immunity }\end{array}$ \\
\hline II27ra & Interleukin 27 receptor, alpha & 2.99 & 0.026 & $\begin{array}{l}\text { Cell-mediated immunity, Th1 } \\
\text { and Th2 immune responses }\end{array}$ \\
\hline Cd40lg & CD40 ligand, TNFSF5 & 2.93 & 0.037 & $\begin{array}{l}\text { CD4+ T-Cell Markers, other Th1- } \\
\text { related genes, cell-mediated } \\
\text { immunity }\end{array}$ \\
\hline Ptprc & $\begin{array}{l}\text { Protein tyrosine phosphatase, } \\
\text { receptor type, C }\end{array}$ & 2.92 & 0.037 & $\begin{array}{l}\text { CD4+ T-Cell Markers, cell- } \\
\text { mediated immunity }\end{array}$ \\
\hline Irf4 & Interferon regulatory factor 4 & 2.87 & 0.042 & Other Th2-related genes \\
\hline$\| 3$ & Interleukin 3 & 2.82 & 0.196 & Other Immune Response Genes \\
\hline Tnf & Tumor necrosis factor & 2.64 & 0.043 & $\begin{array}{l}\text { Other Th1-related genes, cell- } \\
\text { mediated and humoral } \\
\text { immunity }\end{array}$ \\
\hline 119 & Interleukin 9 & 2.36 & 0.169 & Other Th2-related genes \\
\hline Tnfsf4 & $\begin{array}{l}\text { Tumor necrosis factor (ligand) } \\
\text { superfamily, member } 4\end{array}$ & 2.34 & 0.085 & $\begin{array}{l}\text { Th1 and Th2 immune response, } \\
\text { cell-mediated immunity, CD4+ } \\
\text { T-Cell Markers }\end{array}$ \\
\hline $\mathrm{Cd} 28$ & CD28 antigen & 2.26 & 0.082 & $\begin{array}{l}\text { Other Th1-related genes, cell- } \\
\text { mediated and humoral } \\
\text { immunity }\end{array}$ \\
\hline $\mathrm{Cd} 27$ & CD27 antigen & 2.25 & 0.029 & $\begin{array}{l}\text { Cell-mediated immunity, CD4+ } \\
\text { T-Cell Markers }\end{array}$ \\
\hline Stat4 & $\begin{array}{l}\text { Signal transducer and activator } \\
\text { of transcription } 4\end{array}$ & 2.23 & 0.067 & Th1 markers \\
\hline $\mathrm{Ccl5}$ & $\begin{array}{l}\text { Chemokine (C-C motif) ligand 5, } \\
\text { RANTES }\end{array}$ & 2.07 & 0.030 & Th2-related genes \\
\hline II2ra & $\begin{array}{l}\text { Interleukin } 2 \text { receptor, alpha } \\
\text { chain }\end{array}$ & 2.01 & 0.048 & $\begin{array}{l}\text { Other Th1-related genes, Th2 } \\
\text { markers }\end{array}$ \\
\hline $\mathrm{Cd} 80$ & CD80 antigen & 2.00 & 0.040 & Th1-immune response, CD4+ T- \\
\hline & & & & Cell Markers \\
\hline Gata3 & GATA binding protein 3 & -2.01 & 0.289 & Th2 markers \\
\hline Junb & $\begin{array}{l}\text { Jun-B oncogene, Transcription } \\
\text { factor jun-B }\end{array}$ & -2.04 & 0.008 & Other Th2-related genes \\
\hline Ccr2 & $\begin{array}{l}\text { Chemokine (C-C motif) } \\
\text { receptor } 2\end{array}$ & -2.28 & 0.016 & Th1 and Th2 immune response \\
\hline Socs 5 & $\begin{array}{l}\text { Suppressor of cytokine } \\
\text { signaling } 5\end{array}$ & -2.57 & 0.037 & Th1 and Th2 immune response \\
\hline Cebpb & $\begin{array}{l}\text { CCAAT/enhancer binding } \\
\text { protein (C/EBP), beta }\end{array}$ & -2.62 & 0.135 & Other Th2 related genes \\
\hline $\mathrm{Ccl} 7$ & $\begin{array}{l}\text { Chemokine (C-C motif) ligand 7, } \\
\text { MCP-3 }\end{array}$ & -2.91 & 0.118 & Other Th2 related genes \\
\hline Il13ra1 & Interleukin 13 receptor, alpha 1 & -3.03 & 0.015 & Other Th2 related genes \\
\hline Pcgf2 & Polycomb group ring finger 2 & -3.17 & 0.044 & Other Th2 related genes \\
\hline II18r1 & Interleukin 18 receptor 1 & -3.76 & 0.043 & Other Th1 related genes \\
\hline Vegfa & $\begin{array}{l}\text { Vascular endothelial growth } \\
\text { factor A }\end{array}$ & -5.54 & 0.061 & Th1 immune response \\
\hline Tgfb3 & $\begin{array}{l}\text { Transforming growth factor, } \\
\text { beta } 3\end{array}$ & -6.94 & 0.034 & CD4+ T-Cell Markers \\
\hline Col11 & $\begin{array}{l}\text { Chemokine (C-C motif) ligand } \\
11 \text {, Eotaxin }\end{array}$ & -7.02 & 0.031 & Other Th2 related genes \\
\hline Csf2 & $\begin{array}{l}\text { Colony stimulating factor } 2 \\
\text { (granulocyte-macrophage), } \\
\text { GM-CSF }\end{array}$ & -9.33 & 0.036 & Other Th1 related genes \\
\hline Spp1 & $\begin{array}{l}\text { Secreted phosphoprotein } 1 \\
\text { (Osteopontin) }\end{array}$ & -26.54 & 0.006 & $\begin{array}{l}\text { Other genes involved in } \\
\text { inflammatory response }\end{array}$ \\
\hline Sftpd & Surfactant associated protein D & -633.23 & 0.041 & $\begin{array}{l}\text { Other genes involved in } \\
\text { immune response }\end{array}$ \\
\hline
\end{tabular}

Out of all 84 genes, only genes with fold-change $>=2$ are listed in this table. Genes are color-coded according to a response, red: Th1 related genes, blue: Th2 related genes, green: Th1 and Th2 responses, black: other genes involved in immune response 
metabolic, biochemical or endocrine pathways in offspring. However, our study only explored inflammation and immune pathways and does not offer an explanation for this adverse effect.

\section{Cu NP exposure during gestation affected immune/ inflammatory responses in mothers}

We found significantly higher inflammatory responses in the lungs of both pregnant and non-pregnant mice exposed to $\mathrm{Cu}$ NPs during GD 3 - 19 compared to pregnant and non-pregnant shams. This was represented by significantly higher numbers of total leukocytes and neutrophils in the BAL fluid. Production of Th1, Th2 or other cytokines/chemokines in BAL fluid was significantly higher in the non-pregnant group exposed to Cu NPs than in the exposed pregnant group. Exposed non-pregnant mice had also a higher systemic inflammation than pregnant exposed mice. Our data suggest that the Th2 pregnancy environment partially protected the lungs of the pregnant mice from the pro-Th1 effects of the Cu NPs. The histopathology score of perivascular cuffing (represented by lymphocytes and plasma cells surrounding blood vessels) in nanoparticle-exposed mice was also 2.4-fold higher in non-pregnant (1.8) than pregnant mice (0.75). We did not observe a clear polarization of Th1 or Th2 cytokines in BAL fluid of dams exposed to $\mathrm{Cu}$ NPs during gestation.

Several animal studies have reported on differences in pulmonary inflammatory responses among pregnant and non-pregnant rodents. Contrary to our study presented here, several previous studies found pregnant rodents to be more susceptible to various inflammatory stimuli than non-pregnant animals. For example, pregnant rats had an enhanced inflammatory response to inhaled endotoxin [31] or acute ozone exposure [32] when compared to non-pregnant controls. Similarly, much stronger pulmonary inflammation was observed in pregnant mice than in non-pregnant females after intra-nasal instillation of $\mathrm{TiO}_{2}$ or diesel exhaust particles [7]. The enhanced inflammation in pregnancy after $\mathrm{TiO}_{2}$ particle exposure was recently associated with impaired uptake of particles by macrophages due to estradiol release during pregnancy [33].

Based on our previous results [26, 27], we expected that $\mathrm{Cu}$ NP inhalation exposure would cause an immense inflammatory response; however, we wondered whether the pregnancy phenotype (characterized by predominant Th2 response) would have an effect on this inflammatory response in pregnant vs. non-pregnant mice. Furthermore, we sought to explore if enhanced inflammation during pregnancy would modulate the immune system of the developing fetus. The immunomodulatory effects of various nanomaterials have been reported previously, e.g. maternal exposure to combustion-generated ultrafine particles inhibited pulmonary Th1 maturation and enhanced asthma development in offspring [6]. Indeed, we observed a significant inflammatory response in the lungs of exposed animals. However, this response was larger in the non-pregnant mice than in their pregnant counterparts. This finding might be explained by the fact that pregnancy dominated with Th2 response is a state of maternal suppression with anti-inflammatory effects, and thus, the competition between anti-inflammatory effects of pregnancy and inflammatory effects of $\mathrm{Cu}$ NPs may have occurred. Suppression of allergic pulmonary inflammation was also found in asthmatic mice that were exposed to fine or nanosized $\mathrm{TiO}_{2}$ particles suggesting that the immunological status of the exposed mice determines the modulation of the airway inflammation [34]. To offer more definite explanations for these findings, studies with different types of nanomaterials with various physicochemical properties and further evaluation of inflammation and endocrine pathways are warranted. Recently, a study by Jones et al. [35] suggested that Th1-Th2 balance is an important factor in NP clearance, the authors demonstrated an increased clearance of NPs in Th2-prone mice. However, clearance of particles is also dependent on the physicochemical properties of nanomaterials as mentioned earlier. Furthermore, in our study there was a physiological increase of $\mathrm{Cu}$ levels during pregnancy and thus, assessment of the clearance of particles in our study is more complex. We could not determine how much of the increased $\mathrm{Cu}$ levels was due to a physiological increase during pregnancy and how much was due to exposure to $\mathrm{Cu}$ NPs.

\section{No translocation of $\mathrm{Cu}$ ions into the placenta or fetus was observed by ICP-MS}

Nanoparticle translocation from the lung into circulation and secondary target organs after inhalation exposure has been previously reported [36, 37] and is very much dependent on the particle size, surface area, charge, and functionality, as well as solubility. The translocation of NPs to fetus has been reported as very low and mainly occurring after intravenous exposure [38-40]. Cu NPs were shown to be highly soluble in artificial lung fluid [26]. Thus, we hypothesized that translocation of $\mathrm{Cu}$ NPs into the blood stream and possibly to the fetus was more probable than in studies with non-soluble particles. However, our study did not find any increased $\mathrm{Cu}$ levels in the placentas or fetuses. Similarly, we did not observe translocation of $\mathrm{Cu}$ NP to other tissues in our previous sub-acute inhalation study [27]. The levels of $\mathrm{Cu}$ ions in the blood of exposed dams were not significantly higher than in their control counterparts. Pregnancy itself increased the levels of $\mathrm{Cu}$ ions in the blood, irrespective of the $\mathrm{Cu} \mathrm{NP}$ exposure. On the other hand, some of the nanoparticles were likely cleared from the lungs by the mucociliary escalator to the trachea and digestive system or lymphatic system, but this was not determined in this study. 
Our result of increased $\mathrm{Cu}$ levels in blood during pregnancy is in an agreement with the results of existing human studies [41-44]. Many of them report a 2-fold increase of $\mathrm{Cu}$ levels in blood at full term, as was also seen in our study. The increase of $\mathrm{Cu}$ levels in lungs of exposed mice was approximately 4-fold, in both pregnant and nonpregnant mice. The levels of $\mathrm{Cu}$ in other organs were not determined in this study. It is possible that only a very small percentage of delivered material (in the particle form or in the form of $\mathrm{Cu}$ ions after potential dissolution) translocated into the blood and other target organs as was reported in other studies $[38,45,46]$ and we were unable to detect the $\mathrm{Cu}$ using the ICP-MS method, which was a limitation of this study. Interestingly, we saw retention of $\mathrm{Cu}$ in the lungs 7 wks after exposure; there was still 34 and $37 \%$ retained $\mathrm{Cu}$ from the original amount found in the lung at the end of gestation in pregnant and non-pregnant exposed groups, respectively.

\section{No histopathological changes in the placental tissues were found}

Inhalation of particles during pregnancy may induce acute placental inflammation [47] that can lead to inadequate placental perfusion and decrease transplacental nutrient exchange [48]. Several studies found that inhaled or injected NPs enter the circulatory system and can migrate to various organs or tissues $[49,50]$. Particles containing lead and nickel were found in human placentas from subjects living in proximity to polluted areas [51]. The accumulation of environmental pollutants in the placenta may cause hypoxia that can result in enzymatic changes. The increased activity of lactate dehydrogenase (LDH) was found in human placentas from women residing in areas polluted with fine metal particles [52]. The pollutants captured in the placental tissue may diminish placental function via impairment of placental microstructure [53]. Thus, even if the direct translocation of NPs from mother to fetus would not occur, NPs that are taken up by the placenta may cause placental functional changes and subsequently have an impact on the developing fetus. Damaging effects observed in fetuses after i.v. administration of silica NPs were linked to structural and functional changes in the placenta only at the highest concentration of $0.8 \mathrm{mg}$ per mouse [39]. Inhalation of diesel exhaust caused immunological changes in the placentas of exposed mice [54]. Our study did not find any histopathological changes in the placental tissues (Additional file 1). Functional changes of the placentas potentially caused by $\mathrm{Cu}$ NP exposure were not evaluated in this study, but since we found a significantly lower survival rate of pups that were prenatally exposed to $\mathrm{Cu}$ NPs, as well as changes in immunological responses of exposed mothers, functional changes are not excluded and should be investigated further.

\section{Prenatal inhalation exposure to $\mathrm{Cu}$ NPs induced gene expression changes in Th1/Th2 or other immune responses in spleenic mRNAs in offspring}

In utero exposure to xenobiotics has been proposed as an important driver for gene reprogramming that may lead to the development of higher vulnerability or resistance to various diseases. The spleen is the largest lymphatic organ and is the primary site of innate and adaptive immune processes, and along with the bone marrow, it is the main organ involved in the manufacturing, maturation, differentiation, proliferation and storage of immune cells.

Of 84 genes involved in T helper cell (Th cell) immune responses that were determined in spleenic RNAs of pups at 50 PNDs with prenatal exposure to $\mathrm{Cu}$ NPs, a number stood out as having potential health links. For one, mRNA encoding Surfactant associated protein D (Sftpd) was found to be the most down-regulated (633-fold) compared to controls $(p<0.04)$. Surfactant protein (SP)-D plays an important role in pulmonary innate immunity. But it is also known to be involved in non-pulmonary modulation of inflammation [55]. The presence of SP-D in extrapulmonary tissues has been reported in various mammals [56]. As reviewed by others $[57,58]$ SP-D mediates many mechanisms such as opsonization of pathogens, activation of phagocytosis and modulation of toll-like receptor (TLR) activity. It was also suggested that surfactant proteins, both SP-A and SP-D, can modulate the immune response to allergens and/or development of allergic reactions [59]. A protective role of SP-D in the pathogenesis of allergic airway disease was found (a study using wild type or SP-D-/- mouse model challenged with house dust mite antigen) [60]. Many other immune roles pulmonary and extrapulmonary are reviewed by Nayak et al. [61].

Another gene that was found to be significantly $(p<0.01)$ down-regulated (27-fold) in prenatally exposed pups was Secreted phosphoprotein 1 (Spp1; also known as Osteopontin). Spp1 was found to modulate immune responses at several levels: recruits cells to sites of inflammation, assists in cell attachment and wound healing, mediates cell activation and cytokine production through interaction with cellular signaling pathways, and it is involved in specific apoptosis pathways. During inflammation it stimulates both pro- and anti-inflammatory processes. Deficiency of this protein is connected to reduced Th1 immune responses in infectious diseases, autoimmunity and delayed type of hypersensitivity [62].

Granulocyte/macrophage colony-stimulating factor (GMCSF; also known as Csf2) stimulates proliferation, activation, and differentiation of macrophages, granulocytes, neutrophils, eosinophils, and monocytes [63]. The gene of this protein was also found to be significantly $(p<0.05)$ down-regulated (9-fold) in the pups' spleens.

The three most up-regulated genes in the pups' spleens were Lymphotoxin- $\alpha$ (Lt- $\alpha$, also known as tumor necrosis 
factor- $\beta$, [TNF- $\beta]$ ) 6 -fold $(p<0.05)$, Gfil (Growth factor independent 1 ) 5-fold $(p<0.02)$, and IL-10 (4-fold, $p<0.005$ ).

Lt- $\alpha$ is a cytokine produced by lymphocytes and a member of the TNF family. It is essential in the organogenesis of secondary lymphoid organs (spleen, lymph nodes, and Peyer's patches) and may induce the development of tertiary lymphoid tissue (accumulation of lymphoid cells in chronic inflammation). Other genes related to the TNF family (ligands or receptors) were also up-regulated, some significantly so, such as Tnf 2.6 -fold $(p<0.04)$, Cd40lg (CD40 ligand, TNFSF5) 3-fold $(\mathrm{p}<0.03)$ and Tnfrsf8 (Tnf receptor superfamily, member $8,1.6$-fold, $p<0.03$ ) and Tnfsf4 (Tnf (ligand) superfamily, member 4) was upregulated (2-fold) but not significantly $(p<0.09)$.

Gfi1 (Growth factor independent 1) is a transcriptional repressor that is induced during T-cell differentiation and plays a critical role in enhancing Th2 cell expansion by promoting proliferation and preventing apoptosis. It has been suggested that it works synergistically with Gata3 and provides a mechanism through which IL-4 could promote Th2 cell expansion [64].

The third most up-regulated gene was IL-10, which is known to inhibit inflammatory pathologies and functions at different phases of immune responses and potentially at different anatomical locations. IL-10 was originally recognized as a Th2-type cytokine, but later evidence suggested that it is more relevant to regulatory $\mathrm{T}$ (TReg) cell responses and now it is considered a much more broadly expressed cytokine. IL-10 is expressed by many adaptive immune cells including Th1, Th2, and Th17 cell subsets, TReg cells, $\mathrm{CD} 8^{+} \mathrm{T}$ cells and B cells [65]. Due to the fact that various cell types can express IL-10 the regulation of this cytokine is quite challenging. In our study it appears that more pro-inflammatory cytokines were expressed in pups. However, the pathways that induce IL-10 expression may also negatively regulate the expression of these proinflammatory cytokines. In many cases, IL-10 is induced together with pro-inflammatory cytokines [65].

\section{Conclusions}

Prenatal exposure to $\mathrm{Cu}$ NPs caused a profound pulmonary inflammation in dams with negative effect on pups' survival after delivery. Many up- and down-regulated genes related to Th1/Th2 type responses point to immunomodulatory effects of $\mathrm{Cu}$ NPs in offspring after prenatal inhalation exposure. Our study demonstrated that prenatal exposure to $\mathrm{Cu}$ NPs trigger a potent immune Th1/Th2 response in offspring that appear to be activating many pro-inflammatory pathways. However, there was no strong skew either to Th1 or Th2 immune responses in either dams or offspring. We conclude that the changes in expression of immuneresponse genes in the pups with prenatal $\mathrm{Cu} \mathrm{NP}$ exposure are due to changes in inflammatory and immune responses of mothers caused by inhalation of $\mathrm{Cu}$ NPs rather than due to direct effect of NPs on fetus, since no translocation of $\mathrm{Cu}$ was observed through the placenta to the fetus. Further investigation focused on pulmonary prenatal exposure to NPs with postnatal pathogen or allergen challenge, especially in early postnatal stages, might expand our understanding of immunotoxicity potential of metal and metal oxide NPs.

\section{Materials and methods}

\section{Nanoparticle characterization}

$\mathrm{Cu}$ NPs with a primary particle size reported by the manufacturer of $25 \mathrm{~nm}$ were purchased from Nanostructured and Amorphous Materials, Inc. (Houston, TX, USA) and used without any further intentional modification. The particles were characterized by X-ray diffraction (XRD) using a Bruker D-5000 q - q X-ray diffractometer with a Kevexsensitive detector (Madison, WI). The primary size of the $\mathrm{Cu}$ NPs was assessed by transmission electron microscopy (TEM, JEOL JEM-1230, Japan) by sizing nearly 1500 particles. X-ray photoelectron spectroscopy (XPS) was used to measure the surface chemical composition of the powdered sample (Ultra-Axis XPS, Kratos, Manchester, UK). The surface area was measured with an automated multipoint Brunauer-Emmett-Teller (BET) surface area apparatus using a nitrogen adsorption method (Quantachrome Nova 4200e, Boynton Beach, FL).

\section{Animals}

Mice (C57Bl/6 males and females, 6 wks old) were purchased from Jackson Laboratories (Bar Harbor, ME). All animals were housed in our AAALAC-accredited vivarium, in polypropylene, fiber-covered cages in HEPAfiltered Thoren caging units (Hazelton, PA). They were acclimatized for 10 days after their arrival and were maintained in the vivarium with a 12-hr light/dark cycle with ad libitum access to food and water. All protocols performed were approved by our Institutional Animal Care and Use Committee. Animal handling and exposures conformed to the NIH Guide for the Care and Use of Laboratory Animals. Timed pregnancies were established by mating 2 nulliparous females with one single mature male for two days. Each morning the presence of vaginal plug was assessed and if found, the event was considered as gestation day (GD) 1 .

\section{Study experimental design}

Pregnant $(n=9)$ and non-pregnant mice $(n=10)$ were exposed to atmospheres of $\mathrm{Cu} \mathrm{NP}$-aerosol by inhalation for $4 \mathrm{hr} /$ day in a dynamic whole-body exposure chamber from GD 3 - to GD 19 (total of 17 days). The average mass concentration of nanoparticle-laden aerosol in the whole-body chamber was $3.5 \pm 1.2 \mathrm{mg} / \mathrm{m}^{3}$ (mean \pm standard deviation). Shams, (control mice) pregnant $(n=10)$ and non-pregnant $(n=10)$ were exposed to HEPA-filtered laboratory air in 
the identical exposure chamber in an adjacent laboratory. The schematic of the study experimental design with the number of mice per each evaluated endpoint is shown in Fig. 1. Pregnant and non-pregnant mice were euthanized with an overdose of isoflurane followed by cervical dislocation, thoracotomy and exsanguination through the heart. One group of dams was euthanized on GD 19 and the pups were delivered by $\mathrm{C}$-section ( 0 wk post exposure). Another group of mice delivered pups spontaneously on GD 18-20; these pups were euthanized at 50 postnatal days (PND, 7 wks from delivery).

\section{Generation of NPs and exposure system}

The exposure as well as the generation system were described previously [66]. Briefly, a dynamic whole-body exposure chamber was used for animal exposure. $\mathrm{Cu} N \mathrm{NP}$ aerosol was generated from suspension of $\mathrm{Cu}$ NPs in water (Optima grade, Fisher Scientific, Pittsburgh, PA) using a 6-jet Collison nebulizer (BGI Inc. Waltham, MA). Suspensions of $\mathrm{Cu}$ NPs in water that were placed into the nebulizer were prepared freshly each day by ultra-sonication with a high frequency probe for $20 \mathrm{mi}$ nutes. A magnetic stir bar was added into the nebulizer to prevent settling the particles. Particle-laden aerosol from the nebulizer passed through a brass drying column heated to $110{ }^{\circ} \mathrm{C}$ and particle neutralizer (containing $10 \mathrm{mCi}{ }^{85} \mathrm{Kr}$ source, TSI Inc., Shoreview, MN) prior to entering the chamber. Mass exposure concentration of generated aerosol was estimated using a gravimetric method. Pre-weighed fiberglass filters $(47 \mathrm{~mm}$ in diameter, Whatman, Middlesex, UK) held in a stainless steel sampler were connected to the exhaust outlet from the whole-body chamber and sampled every 2 hrs with a flow of $24 \mathrm{~L} / \mathrm{min}$. Filters were pre- and post-weighed in a dedicated climate-controlled room using a microbalance (XP26, Mettler Toledo, Mettler-Toledo, Inc., Columbus, $\mathrm{OH})$.

\section{Tissue dosimetry}

$\mathrm{Cu}$ in the blood and lungs from non-pregnant mice and dams immediately after delivery and 50 days later, and in placentas and in pups delivered by C-section on GD 19 were determined using inductively coupled plasma-mass spectrometry (ICP-MS, Perkin-Elmer ELAN DRC II, Norwalk, CT). The method number ITB001A from CDC Laboratory Procedure Manual adapted for digested tissue and $\mathrm{Cu}$ was used for these analyses [67]. Whole blood was collected via heart exsanguination into tubes containing EDTA anticoagulant and stored at $4{ }^{\circ} \mathrm{C}$ until analyses. Whole blood was then diluted $50 \mathrm{x}$ using a diluent composed of isopropanol $(1 \% \mathrm{v} / \mathrm{v})$, tetramethyl ammonium hydroxide $(1 \% \mathrm{v} / \mathrm{v})$, Triton X-100 $(0.5 \% \mathrm{v} / \mathrm{v})$ and ammonium pyrolidine dithiocarbamate $(0.1 \% \mathrm{w} / \mathrm{v})$ in deionized water. Lung tissue (left lobe) and placentas were excised and stored at $-80{ }^{\circ} \mathrm{C}$. All tissues were then dried using a Speed Vac concentrator (Savant SPD111V, Thermo Scientific, Waltham, MA). Intact carcasses of pups were dried in the oven at $100{ }^{\circ} \mathrm{C}$ for $5 \mathrm{hrs}$. Dry tissues were then weighed and digested in a HotBlock ${ }^{\mathrm{ma}}$ digestion system (Environmental Express, Mt. Pleasant, SC) at $95-98{ }^{\circ} \mathrm{C}$ using $0.25 \mathrm{~mL}$ of high purity concentrated nitric acid (Fisher Optima ${ }^{\circ}$ grade). After cooling to room temperature, the samples were diluted to $5.0 \mathrm{~mL}$ using deionized water. Determination of total $\mathrm{Cu}$ in the whole blood and digested tissues was performed using an ICP-MS with high-purity argon (99.99 \%), a PFA-ST nebulizer (Elemental Scientific, Omaha, NE) and a $0.50 \mathrm{~mm}$ i.d. capillary connected to a cyclonic spray chamber. Sample data were acquired by using 20 sweeps/reading, 1 reading/replicate, and a dwell time of $50 \mathrm{~ms}$. Argon nebulizer gas flow rate was optimized daily from 0.5 to $0.9 \mathrm{~L} / \mathrm{min}$. Data were acquired in counts per second (cps). The following isotopes were selected: ${ }^{63} \mathrm{Cu}$ and ${ }^{65} \mathrm{Cu}$. Analytical calibration standards were prepared from a single-element stock solution containing $1 \mathrm{~g} / \mathrm{L}$ of $\mathrm{Cu}$ stock solution (SPEX, Metuchen, NJ). For the whole blood measurements, the standards were diluted as follows: $1,5,10,20,50,100,500,1000$, and $2000 \mu \mathrm{g} / \mathrm{L}$ in the same diluent as used for the whole blood. For determination of $\mathrm{Cu}$ in tissues and whole bodies, following standard concentrations were used: $1,5,50,100$, 500, and $1000 \mu \mathrm{g} / \mathrm{L}$ in $2 \%$ nitric acid. The method detection limit for $\mathrm{Cu}$ was less than $1 \mu \mathrm{g} / \mathrm{kg}$. Rhodium was included in the diluents at $10 \mu \mathrm{g} / \mathrm{L}$ as an internal standard.

\section{Estimated deposited dose}

The estimated pulmonary deposited dose in this study was $141 \mu \mathrm{g} /$ mouse. We assumed a minute volume of $25 \mathrm{~mL} / \mathrm{min}$ and a deposition fraction of 0.4 in tracheobronchial and pulmonary region combined. Deposition fraction for $36 \mathrm{~nm}$ particles was estimated based on the computational modeling of regional deposition fraction for mice reported by Asgharian et al. [68].

\section{BAL fluid and plasma evaluation}

To assess pulmonary inflammatory response, BAL was performed in dams after C-section and 7 wks later and in 7-wk-old pups. Lungs were washed 3 times with about $1 \mathrm{~mL}$ of $0.9 \%$ sterile sodium chloride solution (Baxter, Deerfield, IL). BAL was centrifuged at $800 \times \mathrm{g}$ for 5 min at $4{ }^{\circ} \mathrm{C}$, supernatants were frozen at $-80{ }^{\circ} \mathrm{C}$ for later cytokines/chemokines analyses and cells were resuspended in Hank's balanced salt solution (Life Technologies, Grand Island, NY). The total number of cells was counted using a hemocytometer. The rest of the cell suspension was fixed on microslides with fetal calf serum (Cytospin 4, Thermo Shandon, Thermo Scientific, Waltham, MA), and stained using Protocol ${ }^{\circ}$ HEMA 3 stain set (Fisher Diagnostics, Pittsburgh, PA). Differential cell 
counts (number of macrophages, neutrophils, lymphocytes, and eosinophils) were determined by counting 400 cells using an optical microscope (Olympus, Center Valley, PA). Cytokines/chemokines in BAL fluid supernatants and plasma of dams/non-pregnant mice and pups were analyzed using a multiplex magnetic bead assay (Luminex 100, Bio-Rad Laboratories, Inc., Hercules, CA).

\section{Gene expression by RT-qPCR (reverse transcription real-time quantitative polymerase chain reaction) RNA Isolation}

Lungs and spleens ( $30 \mathrm{mg}$ of each tissue) from exposed and unexposed 7-wk-old pups were fixed in RNAlater RNA stabilization reagent (SABiosciences, Qiagen, Valencia, CA, USA) and stored at $-20{ }^{\circ} \mathrm{C}$ until RNA isolation. Total RNA was extracted using the RNeasy Mini Kit (Qiagen) after tissue homogenization in RLT buffer with the addition of $\beta$-mercaptoethanol using a handheld homogenizer. Genomic DNA was removed utilizing RNase-Free DNase Set (Qiagen). The quality and quantity of a selected number of isolated RNAs were assessed using the Experion automated electrophoresis system (Bio-Rad Laboratories, Inc., Hercules, CA) and the Experion RNA StdSens Analyses kit according to manufacturer's instructions. The quality of the RNA was considered sufficient if the 28S/18S rRNA (ribosomal RNA) ratio was between 1 and 2 and RNA Quality Indicator (RQI) was $>8$. All samples were also checked by the NanoDrop spectrophotometer (Thermo Fisher Scientific, Wilmington, $\mathrm{DE}$ ); the $\mathrm{OD}_{260} / \mathrm{OD}_{280}$ ratio between 1.82.0 was considered acceptable.

Isolated RNA $(0.5 \mu \mathrm{g})$ was converted to cDNA using the $\mathrm{RT}^{2}$ First strand kit and mixed with $\mathrm{RT}^{2}$ qPCR SYBR Green mastermix (SABiosciences, Qiagen). Samples were loaded onto a 96-well PCR array (Mouse Th1 \& Th2 Responses $\mathrm{RT}^{2}$ Profiler PCR Array, PAMM-034ZA) according to manufacturer's instructions and read using a CFX96 Touch Real-Time PCR Detection System (BioRad Laboratories, Inc., Hercules, CA). The thermocycling conditions were 1 cycle of $95{ }^{\circ} \mathrm{C}$ for $10 \mathrm{~min}$ (HotStart DNA Taq Polymerase activation) followed by 40 cycles of $95{ }^{\circ} \mathrm{C}$ for $15 \mathrm{~s}$ and $60{ }^{\circ} \mathrm{C}$ for $1 \mathrm{~min}$ (fluorescence data collection). Melting curves were performed each time from $55{ }^{\circ} \mathrm{C}$ to $95{ }^{\circ} \mathrm{C}$ with increments of $0.5{ }^{\circ} \mathrm{C}$ for $5 \mathrm{~s}$ to ensure that only one amplification product was formed.

\section{Histopathology}

Lungs (right lobes) after BAL were perfused via the cannulated trachea and fixed in $10 \%$ zinc formalin (Fisher Scientific, Kalamazoo, MI). Placentas of dams after C-section delivery were harvested and also fixed in $10 \%$ zinc formalin. Tissues were then paraffin-embedded, sectioned (5- $\mu \mathrm{m}$ thickness) and stained with hematoxylin and eosin (H\&E). All tissues were evaluated by a board-certified veterinary pathologist for key histopathologic changes including but not limited to inflammatory cell infiltration, fibrosis and cellular injury and necrosis.

\section{Statistical analyses}

All data are expressed as mean \pm standard error (SE) unless otherwise noted. The data were analyzed using a T-test or one-way analysis of variance (ANOVA) followed by a Tukey test if treatment group sizes were equal. Dunn's test was used in cases when treatment group sizes were unequal. If the Normality Test failed, Kruskal-Wallis one-way ANOVA on Ranks was used. If the Equal Variance test failed, data were analyzed using the Mann-Whitney Rank Sum Test (Sigma Plot v.11.0, Systat Software Inc., Point Richmond, CA). The LIFETEST procedure and Wilcoxon Chi-square test were used to compare survival rates of exposed and control pups. The GLM procedure was used to assess differences in weight gain in dams and pups (SAS software Version 9.4, SAS Institute Inc., Cary, NC). The 84 genes that were assessed in the array related to Th1 and Th2 responses were analyzed using the $\mathrm{RT}^{2}$ Profiler PCR Array data Analysis software version 3.5 (http://pcrdataanalysis. sabiosciences.com/pcr/arrayanalysis.php, SABiosciences, Qiagen). A global mean approach was used for normalization of all samples. A $p$-value less than 0.05 was considered statistically significant.

\section{Additional file}

Additional file 1: Placenta histopathology. Representative micrographs of placenta sections stained with H\&E from mice exposed prenatally to Cu NPs or laboratory air (shams). No significant pathological changes were found in the placentas from exposed animals compared to the controls. Bars $=200 \mu \mathrm{m}$ (inset, bars $=20 \mu \mathrm{m}$ ). $\mathrm{A}=$ labyrinth layer, $\mathrm{B}=$ spongiotrophoblast layer, $\mathrm{C}=$ decidual layer. (PDF $322 \mathrm{~kb}$ )

\section{Competing interests}

The authors declare that they have no competing interests.

\section{Authors' contributions}

AA-D initiated and designed the studies, conducted animal exposures, biological assays, collected and processed particle size distribution data, data analysis, and drafted the manuscript. MMM helped with data interpretation, assisted with manuscript drafting and edited the final manuscript, LSP helped with rtPCR analyses, KNG-C performed histopathology evaluation, PST assisted in the design of the study and edited the final manuscript. All authors read and approved the final manuscript.

\section{Acknowledgements}

The study was supported by NIEHS/NIH P30 ES005605. We thank Dr. Imali Ama Mudunkotuwa for nanoparticle characterization, Dr. Vicki Grassian for helpful discussions, Dr. Patrick O'Shaughnessy and Ralph Altmaier for their technical assistance with particle generation and exposure set up, Dr. Brian Wels (State Hygienic Laboratory at The University of lowa) for ICP-MS analyses, and Dr. Kevin Kelly for his help with statistical analyses.

\section{Author details}

${ }^{1}$ Department of Occupational and Environmental Health, University of lowa, College of Public Health, UI Research Park, IREH 170, lowa City, IA 52242, USA. ${ }^{2}$ Department of Internal Medicine, University of lowa, lowa City, IA 
52242, USA. ${ }^{3}$ Department of Pathology, University of lowa, lowa City, IA 52242, USA.

Received: 15 May 2015 Accepted: 21 September 2015 Published online: 06 October 2015

\section{References}

1. Schwartz J. Air pollution and blood markers of cardiovascular risk. Environ Health Perspect. 2001;109 Suppl 3:405-9.

2. Peters A, Liu E, Verrier RL, Schwartz J, Gold DR, Mittleman M, et al. Air pollution and incidence of cardiac arrhythmia. Epidemiology. 2000;11(1):11-7.

3. Franck U, Odeh S, Wiedensohler A, Wehner B, Herbarth O. The effect of particle size on cardiovascular disorders - The smaller the worse. Sci Total Environ. 2011:409(20):4217-21.

4. Pope 3rd CA, Burnett RT, Thun MJ, Calle EE, Krewski D, Ito K, et al. Lung cancer, cardiopulmonary mortality, and long-term exposure to fine particulate air pollution. JAMA. 2002;287(9):1132-41.

5. Sram RJ, Binkova B, Dejmek J, Bobak M. Ambient air pollution and pregnancy outcomes: a review of the literature. Environ Health Perspect. 2005;113(4):375-82.

6. Wang P, You D, Saravia J, Shen H, Cormier S. Maternal exposure to combustion generated PM inhibits pulmonary Th1 maturation and concomitantly enhances postnatal asthma development in offspring. Particle Fibre Toxicol. 2013;10(1):29.

7. Fedulov AV, Leme A, Yang Z, Dahl M, Lim R, Mariani TJ, et al. Pulmonary exposure to particles during pregnancy causes increased neonatal asthma susceptibility. Am J Respir Cell Mol Biol. 2008;38(1):57-67.

8. Schanen BC, Das S, Reilly CM, Warren WL, Self WT, Seal S, et al. Immunomodulation and $\mathrm{T}$ helper $\mathrm{TH}(1) / \mathrm{TH}(2)$ response polarization by $\mathrm{CeO}(2)$ and TiO(2) nanoparticles. PloS ONE. 2013;8(5), e62816.

9. Thompson EA, Sayers BC, Glista-Baker EE, Shipkowski KA, Taylor AJ, Bonner JC. Innate Immune Responses to Nanoparticle Exposure in the Lung. J Environ Immunol Toxicol. 2013;1(3):150-6.

10. Saehana S, Prasetyowati R, Hidayat Ml, Arifin P, Khairurrijal, Abdullah M Performance Improvement of $\mathrm{TiO} 2$ Based Solar Cells by Coating Cu Nanoparticles into the Space between TiO2. AlP Conf Proc. 2011;1415(1):163-6.

11. Kang J, Kim H, Ryu J, Hahn HT, Jang S, Joung J. Inkjet printed electronics using copper nanoparticle ink. J Mater Sci Mater Electron. 2010;21(11):1213-20

12. Torres A, Ruales C, Pulgarin C, Aimable A, Bowen P, Sarria V, et al. Innovative high-surface-area $\mathrm{CuO}$ pretreated cotton effective in bacterial inactivation under visible light. ACS Appl Mater Interfaces. 2010;2(9):2547-52.

13. Allaker RP. The use of nanoparticles to control oral biofilm formation. J Dental Res. 2010;89(11):1175-86.

14. Saunders M. Transplacental transport of nanomaterials. Wiley Interdiscip Rev Nanomed Nanobiotechnol. 2009;1(6):671-84

15. Wick P, Malek A, Manser P, Meili D, Maeder-Althaus X, Diener L, et al. Barrier capacity of human placenta for nanosized materials. Environ Health Perspect. 2010;118(3):432-6.

16. Correia Carreira S, Walker L, Paul K, Saunders M. The toxicity, transport and uptake of nanoparticles in the in vitro BeWo b30 placental cell barrier model used within NanoTEST. Nanotoxicology. 2015;9:66-78.

17. Chu M, Wu Q, Yang H, Yuan R, Hou S, Yang Y, et al. Transfer of quantum dots from pregnant mice to pups across the placental barrier. Small. 2010;6(5):670-8.

18. Blum JL, Xiong JQ, Hoffman C, Zelikoff JT. Cadmium associated with inhaled cadmium oxide nanoparticles impacts fetal and neonatal development and growth. Toxicol Sci. 2012;126(2):478-86.

19. Hougaard KS, Jackson P, Jensen KA, Sloth JJ, Loschner K, Larsen EH, et al. Effects of prenatal exposure to surface-coated nanosized titanium dioxide (UV-Titan). A study in mice Particle and fibre toxicology. 2010;7:16.

20. Campagnolo L, Massimiani M, Palmieri G, Bernardini R, Sacchetti C, Bergamaschi A, et al. Biodistribution and toxicity of pegylated single wall carbon nanotubes in pregnant mice. Particle Fibre Toxicol. 2013;10:21.

21. Tian X, Zhu M, Du L, Wang J, Fan Z, Liu J, et al. Intrauterine inflammation increases materno-fetal transfer of gold nanoparticles in a size-dependent manner in murine pregnancy. Small. 2013;9(14):2432-9.

22. Jo E, Seo G, Kwon JT, Lee M, Lee B, Eom I, et al. Exposure to zinc oxide nanoparticles affects reproductive development and biodistribution in offspring rats. J Toxicol Sci. 2013;38(4):525-30.
23. Jackson P, Hougaard KS, Boisen AM, Jacobsen NR, Jensen KA, Moller P, et al. Pulmonary exposure to carbon black by inhalation or instillation in pregnant mice: effects on liver DNA strand breaks in dams and offspring Nanotoxicology. 2011;6(5):486-500.

24. Hougaard KS, Campagnolo L, Chavatte-Palmer P, Tarrade A, Rousseau-Ralliard D, Valentino $\mathrm{S}$, et al. A perspective on the developmental toxicity of inhaled nanoparticles. Reprod Toxicol. 2015;56:118-40.

25. Wegmann TG, Lin H, Guilbert L, Mosmann TR. Bidirectional cytokine interactions in the maternal-fetal relationship: is successful pregnancy a $\mathrm{TH} 2$ phenomenon? Immunol Today. 1993;14(7):353-6.

26. Pettibone JM, Adamcakova-Dodd A, Thorne PS, O'Shaughnessy PT, Weydert JA, Grassian VH. Inflammatory response of mice following inhalation exposure to iron and copper nanoparticles. Nanotoxicology. 2008;2(1):189-204.

27. Kim JS, Adamcakova-Dodd A, O'Shaughnessy PT, Grassian VH, Thorne PS. Effects of copper nanoparticle exposure on host defense in a murine pulmonary infection model. Particle Fibre Toxicol. 2011:8:29.

28. Mudunkotuwa IA, Pettibone JM, Grassian VH. Environmental implications of nanoparticle aging in the processing and fate of copper-based nanomaterials. Environ Sci Technol. 2012;46:7001-10.

29. Cassee FR, Freijer Jl, Subramaniam R, Asgharian B, Miller FJ, van Bree L, et al. Development of a model for human and rat airway particle deposition: implications for risk assessment. Bilthoven, the Netherlands: Dutch National Institute of Public Health and Environment (RIVM); 1999.

30. Yoshida S, Hiyoshi K, Oshio S, Takano H, Takeda K, Ichinose T. Effects of fetal exposure to carbon nanoparticles on reproductive function in male offspring. Fertility Sterility. 2010;93(5):1695-9.

31. Huffman $\sqcup$, Frazer DG, Prugh DJ, Brumbaugh K, Platania C, Reynolds JS, et al. Enhanced pulmonary inflammatory response to inhaled endotoxin in pregnant rats. J Toxicol Environ Health. 2004;67(2):125-44.

32. Gunnison AF, Weideman PA, Sobo M. Enhanced inflammatory response to acute ozone exposure in rats during pregnancy and lactation. Fundam Appl Toxicol. 1992;19(4):607-12.

33. Zhang Y, Mikhaylova L, Kobzik L, Fedulov AV. Estrogen-mediated impairment of macrophageal uptake of environmental TiO2 particles to explain inflammatory effect of $\mathrm{TiO} 2$ on airways during pregnancy. J Immunotoxicol. 2015;12(1):81-91.

34. Rossi EM, Pylkkanen L, Koivisto AJ, Nykasenoja $H$, Wolff $H$, Savolainen $K$, et al. Inhalation exposure to nanosized and fine $\mathrm{TiO} 2$ particles inhibits features of allergic asthma in a murine model. Particle Fibre Toxicol. 2010;7:35.

35. Jones SW, Roberts RA, Robbins GR, Perry JL, Kai MP, Chen K, et al. Nanoparticle clearance is governed by Th1/Th2 immunity and strain background. J Clin Invest. 2013;123(7):3061-73.

36. Kreyling WG, Hirn S, Moller W, Schleh C, Wenk A, Celik G, et al. Air-blood barrier translocation of tracheally instilled gold nanoparticles inversely depends on particle size. ACS Nano. 2014;8(1):222-33.

37. Kreyling WG, Semmler-Behnke M, Seitz J, Scymczak W, Wenk A, Mayer P, et al. Size dependence of the translocation of inhaled iridium and carbon nanoparticle aggregates from the lung of rats to the blood and secondary target organs. Inhal Toxicol. 2009;21 Suppl 1:55-60.

38. Semmler-Behnke M, Lipka J, Wenk A, Hirn S, Schaffler M, Tian F, et al. Size dependent translocation and fetal accumulation of gold nanoparticles from maternal blood in the rat. Particle Fibre Toxicol. 2014;11(1):33.

39. Yamashita K, Yoshioka Y, Higashisaka K, Mimura K, Morishita Y, Nozaki M, et al. Silica and titanium dioxide nanoparticles cause pregnancy complications in mice. Nat Nanotechnol. 2011;6(5):321-8.

40. Rattanapinyopituk K, Shimada A, Morita T, Sakurai M, Asano A, Hasegawa T, et al. Demonstration of the clathrin- and caveolin-mediated endocytosis at the maternal-fetal barrier in mouse placenta after intravenous administration of gold nanoparticles. J Vet Med Sci. 2013;76(3):377-87.

41. Vir SC, Love AH, Thompson W. Serum and hair concentrations of copper during pregnancy. Am J Clin Nutr. 1981;34(11):2382-8.

42. Vukelic J, Kapamadzija A, Petrovic D, Grujic Z, Novakov-Mikic A, Kopitovic V, et al. Variations of serum copper values in pregnancy. Srpski arhiv za celokupno lekarstvo. 2012;140(1-2):42-6.

43. Izquierdo Alvarez S, Castanon SG, Ruata ML, Aragues EF, Terraz PB, Irazabal YG, et al. Updating of normal levels of copper, zinc and selenium in serum of pregnant women. J Trace Elem Med Biol. 2007;21 Suppl 1:49-52.

44. Martin-Lagos F, Navarro-Alarcon M, Terres-Martos C, de la Serrana HL-G, PerezValero V, Lopez-Martinez MC. Zinc and copper concentrations in serum from Spanish women during pregnancy. Biol Trace Elem Res. 1998;61(1):61-70. 
45. Kreyling WG, Semmler M, Erbe F, Mayer P, Takenaka S, Schulz H, et al. Translocation of ultrafine insoluble iridium particles from lung epithelium to extrapulmonary organs is size dependent but very low. J Toxicol Environ Health-Part A. 2002:65:1513-30.

46. Moller W, Felten K, Sommerer K, Scheuch G, Meyer G, Meyer P, et al. Deposition, retention, and translocation of ultrafine particles from the central airways and lung periphery. Am J Respir Crit Care Med. 2008;177(4):426-32.

47. Bobak M. Outdoor air pollution, low birth weight, and prematurity. Environ Health Perspect. 2000;108:2

48. Kannan S, Misra DP, Dvonch JT, Krishnakumar A. Exposures to airborne particulate matter and adverse perinatal outcomes: a biologically plausible mechanistic framework for exploring potential effect modification by nutrition. Environ Health Perspect. 2006;114(11):1636-42.

49. Takenaka S, Karg E, Roth C, Schulz H, Ziesenis A, Heinzmann U, et al. Pulmonary and systemic distribution of inhaled ultrafine silver particles in rats. Environ Health Perspect. 2001;109 Suppl 4:547-51.

50. Nemmar A, Hoet PH, Vanquickenborne B, Dinsdale D, Thomeer M, Hoylaerts MF, et al. Passage of inhaled particles into the blood circulation in humans. Circulation. 2002;105(4):411-4

51. Reichrtova E, Dorociak F, Palkovicova L. Sites of lead and nickel accumulation in the placental tissue. Hum Exp Toxicol. 1998;17(3):176-81.

52. Kaiglova A, Reichrtova E, Adamcakova A, Wsolova L. Lactate dehydrogenase activity in human placenta following exposure to environmental pollutants. Physiol Res. 2001;50(5):525-8.

53. Reichrtova E, Palkovicova L, Adamcakova A, Ursinyova M, Ciznar P, McNabb SJN. Metal Particulate Deposits in the Placental Tissue Associated with Microstructural Deviations and Allergic Symptoms in Early Childhood. In: 5th International Technion Symposium of the Austrian Technion Society, Particulate Matter and Health. Vienna, Austria: Austrian Technion Society; 2003.

54. Fujimoto A, Tsukue N, Watanabe M, Sugawara I, Yanagisawa R, Takano H, et al. Diesel exhaust affects immunological action in the placentas of mice. Environ Toxicol. 2005;20(4):431-40.

55. Bourbon JR, Chailley-Heu B. Surfactant proteins in the digestive tract, mesentery, and other organs: evolutionary significance. Comp Biochem Physiol. 2001;129(1):151-61.

56. Herias MV, Hogenkamp A, van Asten AJ, Tersteeg MH, van Eijk M, Haagsman HP. Expression sites of the collectin SP-D suggest its importance in first line host defence: power of combining in situ hybridisation, RT-PCR and immunohistochemistry. Mol Immunol. 2007;44(13):3324-32.

57. Lambertsen KL, Ostergaard K, Clausen BH, Hansen S, Stenvang J, Thorsen SB, et al. No effect of ablation of surfactant protein-D on acute cerebral infarction in mice. J Neuroinflammation. 2014;11:123.

58. Yoshida M, Korfhagen TR, Whitsett JA. Surfactant protein D regulates NF-kappa B and matrix metalloproteinase production in alveolar macrophages via oxidant-sensitive pathways. J Immunol. 2001:166(12):7514-9.

59. Wang JY, Kishore U, Lim BL, Strong P, Reid KB. Interaction of human lung surfactant proteins $A$ and $D$ with mite (Dermatophagoides pteronyssinus) allergens. Clin Exp Immunol. 1996;106(2):367-73.

60. Ogawa H, Ledford JG, Mukherjee S, Aono Y, Nishioka Y, Lee JJ, et al. Surfactant protein $D$ attenuates sub-epithelial fibrosis in allergic airways disease through TGF-ss. Respir Res. 2014;15(1):143.

61. Nayak A, Dodagatta-Marri E, Tsolaki AG, Kishore U. An insight into the immune roles of surfactant proteins, SP-A and SP-D. Front Immunol. 2012:3:131.

62. Wang KX, Denhardt DT. Osteopontin: Role in immune regulation and stress responses. Cytokine Growth Factor Rev. 2008;19(5-6):333-45

63. Hamilton JA. Colony-stimulating factors in inflammation and autoimmunity. Nat Rev. 2008:8(7):533-44.

64. Zhu J, Guo L, Min B, Watson CJ, Hu-Li J, Young HA, et al. Growth factor independent- 1 induced by IL-4 regulates Th2 cell proliferation. Immunity. 2002;16(5):733-44.

65. Saraiva M, O'Garra A. The regulation of IL-10 production by immune cells. Nat Rev. 2010;10(3):170-81.

66. Adamcakova-Dodd A, Stebounova LV, Kim JS, Vorrink SU, Ault AP, O'Shaughnessy PT, et al. Toxicity assessment of zinc oxide nanoparticles using sub-acute and sub-chronic murine inhalation models. Particle Fibre Toxicol. 2014;11:15.
67. United States Centers for Disease Control and Prevention. Method No. ITB001A. Laboratory Procedure Manual 2004 [cited; Available from: http://www.cdc.gov/ nchs/data/nhanes/nhanes_05_06/pbcd_d_met_lead_cadmium.pdf

68. Asgharian B, Price OT, Oldham M, Chen LC, Saunders EL, Gordon T, et al. Computational modeling of nanoscale and microscale particle deposition, retention and dosimetry in the mouse respiratory tract. Inhal Toxicol. 2014;26(14):829-42.

\section{Submit your next manuscript to BioMed Central and take full advantage of:}

- Convenient online submission

- Thorough peer review

- No space constraints or color figure charges

- Immediate publication on acceptance

- Inclusion in PubMed, CAS, Scopus and Google Scholar

- Research which is freely available for redistribution 